\title{
EFFECT OF ORGANIC FOOD-RELATED LIFESTYLE TOWARDS ATTITUDE AND PURCHASE INTENTION OF ORGANIC FOOD: EVIDENCE FROM BRAZIL
}

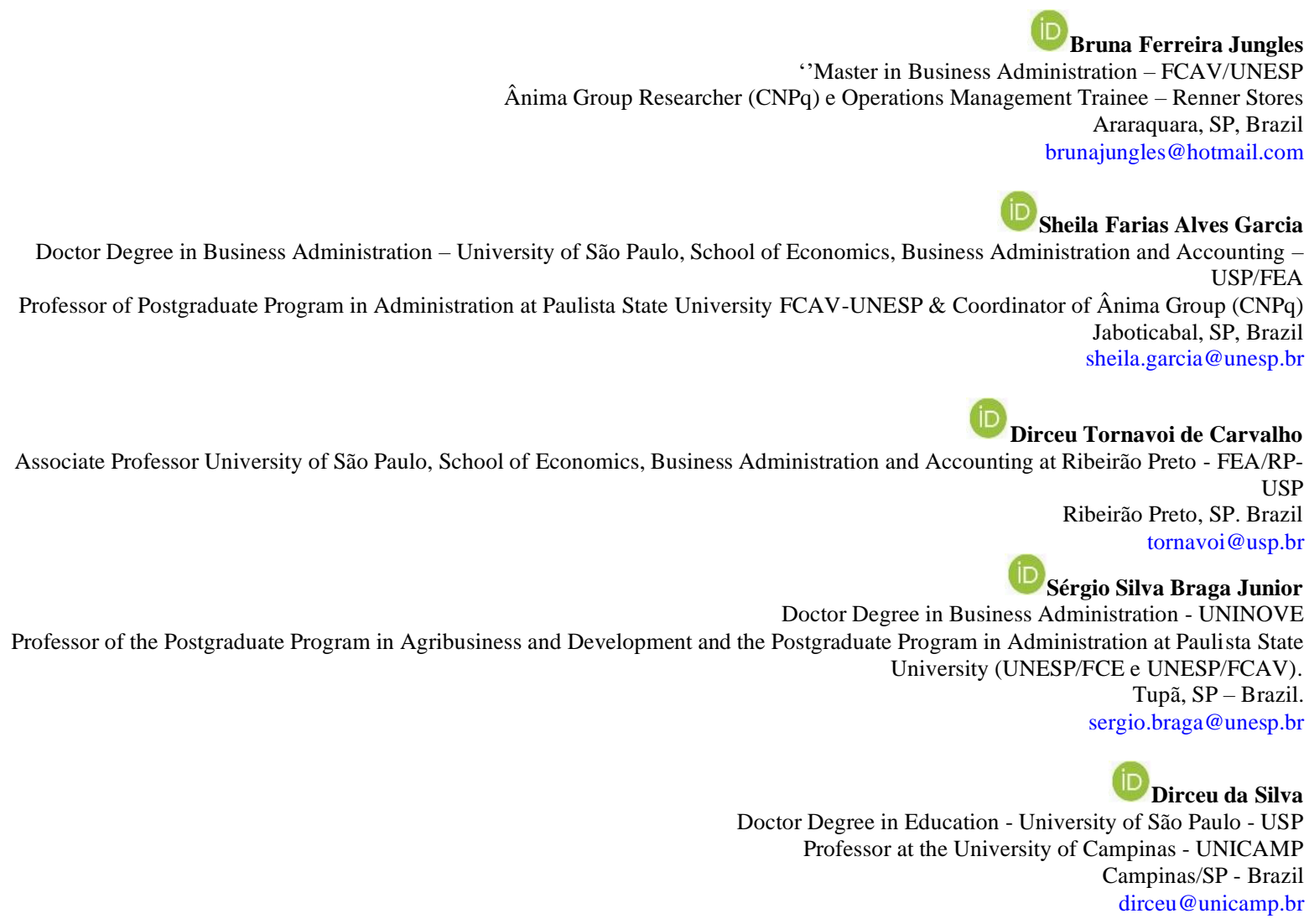

Objective: Analyze the effect of organic food-related lifestyle towards the attitude and purchase intention on organic food in the Brazilian context.

Method: A conceptual framework was developed with a second-order construct, the organic food-related lifestyle (OFRL), to assess its impact on attitude and purchase intention. An online survey was carried out with 651 Brazilian consumers (non-probabilistic sample). The data were analyzed using Structural Equation Modeling, by partial least squares and path models (PLS-PM), using the SmartPLS 2.0 software.

Originality / Relevance: This study extends the literature and provides further insights when analyzing the consequences of the OFRL on the attitude and purchase intention of organic food.

Results: The OFRL is a good predictor for purchase intention of organic food and presents a strong relationship with attitude. The last one plays a mediating role in the relationship OFRL-purchase intention, improving the predict role of the organic food-related lifestyle toward purchase intention. The model explained $19 \%$ of the attitude variance and $51 \%$ of the purchase intention variance.

Theoretical / Methodological Contributions: From a theoretical perspective, this work innovates by proposing a unique second-order construct, composed of latent variables linked to the organic lifestyle, to measure its impact on the formation of attitude and purchase intention toward organic food

Keywords: Consumer Behavior; Attitude; Theory of Planned Behavior; Food-Related Lifestyle; Structural Equation Modeling.

\section{How to cite the article}

American Psychological Association (APA)

Jungles, B. F., Garcia, S. F. A., Carvalho, D. T., Jr. Braga, S. S., \& Silva, D. (2021, Oct./Dec.). Effect of organic food-related lifestyle towards attitude and purchase intention of organic food: evidence from Brazil. Brazilian Journal of Marketing, 20 (4), 267 - 299. https://doi.org/10.5585/remark.v20i4.19192. 


\section{Introduction}

There is an ongoing trend towards organic food in many countries that stimulates food producers and marketers to know the determinants of its consumption (Janssen, 2018; Katt \& Meixner, 2020). Previous empirical research on organic food has broadly analyzed the purchasing decision process, seeking to access the key attributes evaluated by consumers, as well as the benefits and barriers to organic food consumption (Aschemann-Witzel \& Aagaard, 2014; Britwum, Bernard \& Albrecht, 2020; Carfora, Cavallo, Caso, Del Giudice, De Devitiis, Viscecchia \& Cicia, 2019; Ergönül \& Ergönül, 2015; Katt \& Meixner, 2020; Rana \& Paul, 2017; Wekeza \& Sibanda, 2019).

The most valued attributes, in the case of organic food, are not observable before purchase or during consumption. In fact, they are related to the production process and its impact on the environment and human health. They have to be credentialed, which is one of the reasons why these foods used to be certified. Even when these attributes are certificated, the consumers have to be confident that they are really getting those attributes with their purchases. "Analysis of the determinants of organic food consumption is neither simple nor straightforward. [...] willingness to pay (WTP) for organic food is more complex than typically perceived [...]" (Britwum et al., 2021, p.1).

More than attributes, the consumption of organic food is defined by the values and attitudes of its consumers. A systematic review of recent scientific production (1999-2019) revealed that concern for the environment and health, aspects linked to consumer values and attitudes, matter more than aspects related to the product. In most of the studies analyzed, these variables showed a positive and significant influence on WTP (Katt \& Meixner, 2020).

The literature review points to possible relationships between the consumption of organic food and healthy lifestyles. The growing incidence of diseases caused by food choices has led consumers to review their habits, in search of a better quality of life (Rana \& Paul, 2017). In this movement, the consumption of organic food seems to be linked to healthier and more sustainable behavioral patterns, giving rise to a new pro-organic lifestyle (Oroian, Safirescu, Harun, Chiciudean, Arion, Muresan \& Bordeanu, 2017).

There are works that seek to segment organic consumers based on their perceptions and attitudes towards these food products. One of these papers located three segments: 1) Environmentally concerned (52.8\%): focus on sustainability and health; 2) Health concerned (35\%): focus on health and weight concern and 3) Gourmand (12.2\%): focus on health and sensory aspects. The results indicated that the natural and sustainable consumption component 
of the factor analysis (from the method used by author) has high importance in the buying decision process of organic food. It is, alongside satisfying hunger, to organic consumers, food encompasses additional traits that are linked to sustainable development and consumption, but also some ethical aspects such as animal welfare, environmental safety, and the lack of pesticides Oroian et al. (2017). The survey results cannot be generalized (refer to consumers in the North-West Development Region of Romania, but the work raises an important aspect: the lifestyle of organic consumers.

The growth of the organic market is attributed to the change in the consumer's lifestyle (Oroian et al., 2017; Rana \& Paul, 2017). The finding that lifestyle is among the main determinants of organic food consumption has attracted the attention of researchers to understand the relationship between this construct and pro-organic behavior. The literature provides evidence that there is a link between organic food and an active lifestyle (Goetzke \& Sipiller, 2014).

According to Anderson and Golden (1984), the lifestyle approach was integrated in the consumer behavior literature in the 1950's by Bell (1958), Havighurst and Feigenbaum (1959) as well as by Rainwater et al. (1959). Lifestyle research in marketing is primarily used for market segmentation (Plummer, 1974). In a practical way, the lifestyle combines the virtues of demography with the richness and dimensionality of psychological characteristics (Thøgersen, 2017). The concept is defined in marketing literature as patterns of living, expressed by activities, interests and opinions, which generate a characterization capable of representing an individual in a comprehensive way, as well as their interaction with the environment in which they live. Lifestyle is conceived as a mental construct, which is different from, but explains behavior (Grunert, Brunsø \& Bisp, 1993).

In lifestyle research, it is increasingly showed that people can have not just one, but many interconnected lifestyles. In other words, the lifestyle depends of the domain or context analyzed. (Grunert, Brunsø \& Bisp, 1995). In specific situations, lifestyle is assumed to be the backcloth that frames a consumer's perceptions of products and services and guides her choices and behaviors (Thøgersen, 2017).

In the food industry, Grunert, Brunsø and Bisp $(1993,1995)$ proposed a Food-Related Lifestyle (FRL) model characterized for them as a deductive, cognitive approach to lifestyle research. Taking inspiration from Means-End Chain Theory (Gutman, 1982), they define domain-related lifestyle as "the system of cognitive categories, scripts, and their associations, which relate a set of products to a set of values" (Grunert, Brunsø \& Bisp, 1993, p. 13). 
Despite the growing interest in the study of organic consumer behavior and the importance of lifestyle in this context, there are still gaps to be explored. Among them, the relationship between food-related lifestyle and organic consumption. Until the elaboration of this research, no empirical evidence of the impact of food-related lifestyle on the intention to purchase organic food was found.

The purpose of this research is to analyze the effect of food-related lifestyle toward attitude and purchase intention of organic food, based on the classic hierarchical relationship of Theory of Planned Behavior - TPB (beliefs-attitudes-purchase intention). Studies that aim to identify the factors of the food-related lifestyle that correlate to the attitude, and purchase intention of organic food will bring relevant theoretical contributions. It will make it possible to predict trends and guide production, distribution and promotion systems more precisely (Vera, Pérez, Puig \& Montero-Vicente, 2016).

Under the economic prism, the Brazilian market despite the timid movement, when compared to the largest organic consumer countries, has been showing both an increase in sales value, as well as an increase in production and in the number of producers. In 2020 , the Brazilian organic market reached about BRL 5.8 billion, a $30 \%$ growth compared to 2019, according to the Organis Association (ABRAS, 2021). Moreover, this research also contributes with managerial implications, recommendations, and opportunities for the organic food industry.

\section{Literature review}

Many empirical studies have been conducted in order to understand why consumers buy or do not buy organic food and to identify drivers of organic food consumption. A large part of these studies carried out with organic food consumers seek to understand the purchase decision process and assess which are the valued attributes, the desired benefits, and the barriers to consumption of this food category (Britwum et al., 2020; Carfora et al. 2019; Janssen, 2018; Katt e Meixner, 2020; Rana \& Paul, 2017; Wekeza e Sibanda, 2019).

In 2020, a systematic review of the literature, comprising two decades of scientific publication (1999-2019), identified the main determinants of willingness to pay for organic food (Katt \& Meixner, 2020). The results were grouped into three categories of analysis: consumer-related factors, factors related to the product and factors related to the place of purchase. In the category of consumer-related factors, in addition to demographic factors, values and attitudes play an important role, with emphasis on two variables: 1) concern for the 
environment: it presented, in most studies, a strong impact on the willingness to consumption of organic products; 2) health concern, had a positive effect on organic WTP (Katt \& Meixner, 2020).

Also in the same research (Katt \& Meixner, 2020), in the category factors related to product attributes, price is the recurring variable. However, there is no consensus regarding the impact of this variable on the WTP for organic food. On the other hand, some studies revealed a positive impact of price on the willingness to purchase organic products (Hasselbach \& Roosen, Probst et al. 2012; 2015; Zielke, 2010). The lack of consensus makes it appropriate to use this variable to compose the set determinants of organic consumption. In addition to the price, familiarity and involvement with the product, as well as its availability, also affect the WTP. The research does not speak directly about food lifestyle (Katt \& Meixner, 2020).

Despite the growing interest in organic consumer behavior, there are gaps to be explored in the relationship between lifestyle and organic consumption. Goetzke and Sipiller (2014) investigate whether functional and organic food consumers have the same understanding of health, and which health and well-being improving lifestyles are characteristic for them. In order to measure the different well-being and health lifestyles, Activities, Interests and Opinions (AIO) dimensions were adapted to theoretical wellness concepts.

Consumers of functional food have a similar concept of health and well-being to organic consumers, but differ in certain aspects in their way of achieving this. The purchase of organic and functional food is driven by different lifestyles. Overall, the results confirm the link between organic food and an active lifestyle, as well as functional food and a passive lifestyle Goetzke and Sipiller (2014).

It is observed that for consumers, the consumption of organic food is part of a way of life, which results from an ideology, connected to a system of particular values, which affects consumer attitudes and behavior (Hughner et al., 2007). As lifestyles are multidimensional, they depend on multiple interacting factors and can evolve over time and with the individual's circumstances (Aschemann-Witzel et al., 2018).

The literature review in the exploratory stage of this research gave rise to a bibliometric study, which led to the selection of four factors or variables of food-related lifestyle that would be more related to organic consumption. In this article, these variables will be used to compose a second order construct, here called organic food related lifestyle (OFRL), whose impact on the atitude and purchase intention of organic will be analyzed. The present section summarizes 
the state of the art of those organic food-related lifestyle variables and presents the hypotheses of the study.

The results of the bibliometric study led to the selection of four dimensions of food related lifestyle (FRL) (Grunert, Brunsø \& Bisp, 1993; 1995), that, hypothetically, would be more related to organic consumption: importance of product information, price criteria, health and convenience. In this article, how was presented, these dimensions will be used like operational variables, to compose a second order construct, here named organic food related lifestyle (OFRL), whose impact towards atitude and purchase intention of organic food will be analyzed. The present section explain the organic food-related lifestyle, the operational variables and presents the hypotheses of the study.

\subsection{Organic food-related lifestyle}

The second-order organic food-related lifestyle construct is composed of four latent variables, extracted from the FRL (Grunert, Brunsø \& Bisp, 1993; 1995), which function as operational variables of the second order. The FRL scale was developed with the purpose of segmenting consumers according to their eating habits, attitudes and associated values (Grunert, 1993).

Lifestyle defines the pattern of consumption that reflects an individual's choices on how to spend their time and money, choices that play a fundamental role in defining the consumer's identity and their interaction with the environment in which they live. In the case of foods, the constructs intends to measure consumer attitudes towards food, shopping and consumption processes in different contexts, seeking to characterize people by the functions that food plays in their lives and reach the desired consequences (Goetzke \& Sipiller, 2014; Pérez-Cueto, et al., 2010; Thøgersen, 2017;).

The FRL scale was originally composed of 23 dimensions, distributed in the five domains of the food lifestyle (ways of shopping, quality aspects, cooking methods, consumption situations, and purchasing motives), totalizing 69 operational variables. It was proposed to segment consumers according to their dietary lifestyle, so not all variables are directly related to organic food.

Since the application of the full scale would not be necessary or adequate for the purposes of this research, it was identified the dimensions and domains related to organic consumption. So, to develop the research model of this paper, the criteria chosen of the four factors to compose the OFRL was based on:1) the literature review, that postulated the 
importance of those factors for behavior pro-organic consumption; 2) technical evaluation of three specialists (PHD in the field). The relationship between each of the four operational variables with organic food will be explained in the next section.

\section{1.1 Importance of product information}

The literature indicates that the term "organic" is interpreted in different ways, since many consumers are not yet familiar with the patterns and practices of organic production (Chryssochoidis, 2000; Harper \& Makatouni, 2002; Vukasovic, 2013). In addition, there is a wide variety of contexts, whereas consumers do not have the same geographical, demographic, psychographic and behavioral characteristics, besides that the interpretations of the term by producers and regulators may differ from those of consumers (Zanoli \& Naspetti, 2002; Aertsens et al., 2009).

This miscomprehension ends up accentuating the variety of meanings, beliefs and confusions about the concept (Chryssochoidis, 2000; Harper \& Makatouni, 2002; Vukasovic, 2013). One of the alternatives to solve the gaps generated by the multiple beliefs and confusions related to the organic term is to encourage access to information, a function of extreme importance to stimulate demand, since consumers seek an increasing volume of information about products to support their purchasing decisions (Lim, Yong \& Suryadi, 2014; Sangkumchaliang \& Huang, 2012).

In this sense, food labeling is an important strategy to assist consumers during the food choice process and can be an ally for organic market development (Prada, Garrido, \& Rodrigues, 2017). Furthermore, it is proposed to intensively communicate the high value and ethical attributes of organic food to consumers since, for the majority of consumers, the priceperformance ratio rather than price alone appears to be decisive (Piqueras-Fiszman \& Spence, 2015; Rödiger, Plaßmann, \& Hamm, 2016).

The presence of labels on packaged foods, which carry nutritional information and health claims, strongly influences consumers' buying attitude and intentions (Rana \& Paul, 2017), as consumers are increasingly interested in reliable information and the easy comparison between organic and non-organic products (Gottschalk \& Leistner, 2012).

\subsubsection{Price criteria}

The premium price of organic food over conventional foods has been of great interest to researchers, since the price consideration criterion plays a significant role in the decision- 
making process and express one of the most relevant barriers to organic food consumption (Aertsens et al., 2009; Hughner et al., 2007; Gottschalk \& Leistner, 2012; Rödiger \& Hamm, 2015; Shin, 2018).

The concept of WTP refers to the maximum amount of money that an individual is willing to pay for a product or service (Homburg, Koschate \& Hoyer, 2005). In the context of organic food, the WTP has been explored by several studies (Achilleas \& Anastasios, 2008; Essoussi \& Zahaf, 2008; Gerrard et al., 2013; Gonzalez, 2012; Mondelaers, Verbeke \& Huylenbroeck, 2009), since the price of organic food is frequently higher than conventional counterparts due to the unavailability of economies of scale and additional costs in the production process (Aertsens et al., 2009; Konuk, 2017).

However, the often-reported result that organic food prices are an important barrier to purchase is only conditionally useful for professionals. If on the one hand, it has been reported that organic food prices are an important barrier to purchase; on the other hand, the market volume is growing and the consumer behavior trends toward the quality-price ratio indicates reasonable opportunities for organic markets (Rödiger \& Hamm, 2015). Some studies revealed a positive impact of price on the willingness to purchase organic products (Hasselbach \& Roosen, 2015; Probst et al. 2012; Zielke, 2010). The lack of consensus makes it appropriate to use this variable to compose the set determinants of organic consumption (Katt \& Meixner, 2020).

\subsubsection{Health}

There is a consensus that the demand for organic food has increased substantially in the past two decades due to changes in consumer perception of food, which are no longer just a means of satisfying hunger, but have gained multiple dimensions due to consumer concerns about health-related issues (Oroian, et al., 2017). When making decisions related to the choice of food, consumers consider the potential health benefits that the product can provide, due to the growing importance of this factor (Yazdanpanah, Forouzani \& Hojjati, 2015).

It was observed that health-conscious consumers demonstrate a preference for organic food (Ergönül \& Ergönül, 2015; Hemmerling, Hamm \& Spiller, 2015). This growing interest in health-related issues stimulates consumption, because the choice of organic food versus conventional foods is influenced by the perception of the consumers health benefits caused by them (Paul \& Rana, 2012; Yazdanpanah, Forouzani, \& Hojjati, 2015). 
Another highlight is the growing concern of families with the health and nutrition of their children, a factor that encourages the consumption of foods with higher nutritional values, less addictive and derived from natural production methods (Aertsens et al., 2009; Hughner et al., 2007).

Thus, consumer concerns related to health and the positive perception of consumers in relation to the benefits caused by the consumption of organic food would be an important factor that affect the buying behavior of organic food and are able to predict the purchase intention (Ergönül \& Ergönül, 2015; Yazdanpanah, Forouzani, \& Hojjati, 2015).

\subsubsection{Convenience}

Whereas consumers are looking for healthier alternatives, they also hope to facilitate the purchase, preparation and consumption processes, looking for alternatives that maximize their productivity in terms of time and spending during all stages of the food choice process (Reid, Li, Bruwer \& Grunert, 2001).

Changes in lifestyle patterns has shown that consumers started to reduce their time to plan and prepare meals, rising the demand for convenience in food (Oroian, et al., 2017; Rana \& Paul, 2017). Convenient food are defined as partially or fully prepared items in which preparation time, cooking skills or physical efforts have been significantly transferred from the consumer to the food processor or distributor (Capps, Tedford, \& Havlicek, 1985)

With the growth of organic market, the need to make organic products available in the marketplace is also considerable, since availability leads to sales and attracts new customers (Gottschalk \& Leistner, 2012). However, increasingly looking for convenience demands more than fresh organic food, considering that consumers are looking for health and practicality. So, it is important for offering organic food, with a mix of these three elements.

\subsection{Atittude}

Most contemporary definitions of attitude refer to the cognitive and affective organization, both with respect to an object as well as a predisposition to act (McBroom \& Reed, 1992). In the research on consumer behavior, studies were developed on the causal sequence hierarchical belief-attitude-intention, which underpinned the development of several theories, among which stood out, due to their flexibility and power of explication, the Theory of Rational Action (Ajzen \& Fishbein, 1973), and its successor The Theory of Planned 
Behavior (TPB) (Ajzen, 1991). TPB assumes that behavioral intention is determined by attitude, subjective norm, and the perception of behavioral control (Ajzen, 1991).

In the case of consumption of organic food, TPB seems to be consistent, reporting a significant positive relationship between the attitude towards organic food and the purchase intention of these foods (Al-Swidi et al., 2014; Carfora et al., 2019; Kuran \& Mihic, 2014; Meyer-Hofer et al., 2015; Tarkiainen \& Sundqvist, 2005; Thøgersen, 2017; Watanabe, Alfinito \& Hamza, 2020; Yadav \& Pathak, 2016).

Attitude is one of the most important predictors of the intention to buy organic food (; Carfora et al., 2019; Chen \& Lobo, 2012; 2011Watanabe, Alfinito \& Hamza, 2020; Wirth, Stanton \& Wiley), and some studies have confirmed that consumers in general have a positive attitude towards these foods (Aertsens et al., 2009; Harper \& Makatouni, 2002; Vukasovic, 2013), due to two issues: increasing attention to quality and food safety, showing an increase in the demand for healthy, nutritious and safe foods and the development of social responsibility affecting their purchasing behavior (Savelli et al., 2017)

\subsection{Reseach model and hypotheses}

The conceptual framework, presented in Figure 1, is the research model, that positions the OFRL-purchase intention relationship as its central object. The organic food-related lifestyle determinants are formed by latent variables, that function as operational variables (the importance of product information, price criteria, health, and convenience).

\section{Figure 1}

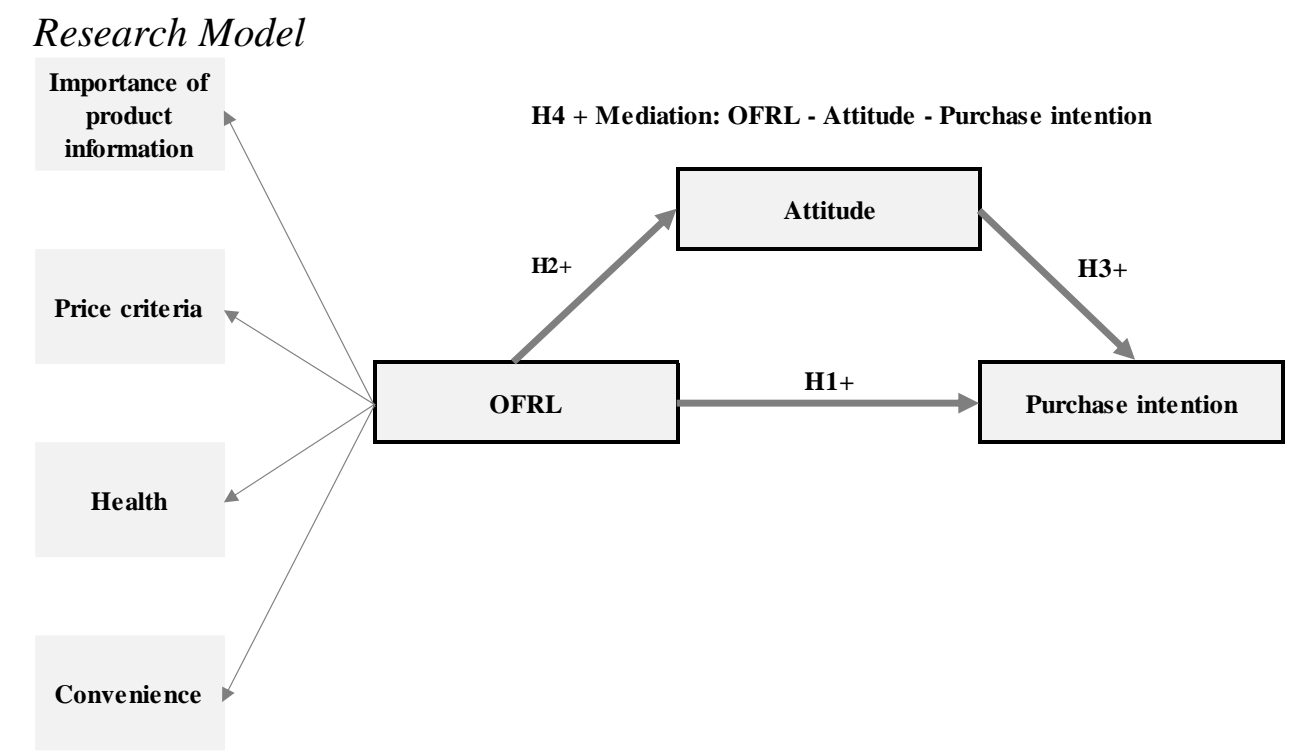

Source: Research results. 
The scales to measure operacional variables were taken from Grunert's (1993) original FRL, which was inspired by Means-End Chain Theory (Gutman, 1982). So, the lifestyle scale was constructed from the connection between beliefs, habits, preferences, and values. FRL model views lifestyle "as part of a hierarchical, cognitive-behavioral system functioning as anorganizing and guiding construct in a person's life" (Thøgersen, 2017, p.2).

In the Literature, there are theoretical statements that suggest the lifestyle affects organic food consumption (Oroian et al., 2017; Rana \& Paul, 2017; Thøgersen, 2017; Vera et al., 2016). This work searched to measure those impacts. Hence it is important to assess whether the organic food-related lifestyle is a good predictor for purchase intention, as hypothesis $\mathbf{H}_{\mathbf{1}}$ assumes.

H1: The OFRL affects positively the purchase intention of organic food.

Considering the relevance of the attitude as a predictor of behavior, it has been studied toward the purchase intention of organic food. Since organic food literature presents attitude as the main predictor of purchase intention (Carfora et al., 2019; Watanabe, Alfinito \& Hamza, 2020), it is important to know how OFRL impact the attitude. It is supposed lifestyle to have a positive impact on the formation of a favorable attitude towards organic food. It is wanted to estimate the power of this relationship.

$\mathbf{H}_{2}$ : The OFRL affects positively the attitude towards organic food.

The same reasons that found the previous hypothesis $(\mathrm{H} 2)$ served to support hypothesis 3. The TPB' literature background of organic food confirms its protagonism to predict future behavior (Aertsens et al., 2009; Al-Swidi et al., 2014; Carfora et al., 2019; Chen \& Lobo, 2012; Harper \& Makatouni, 2002; Kuran \& Mihic, 2014; Meyer-Hofer et al., 2015; Tarkiainen \& Sundqvist, 2005; Thøgersen, 2017; Vukasovic, 2013; Yadav \& Pathak, 2016; Watanabe, Alfinito e Hamza, 2020; Wirth, Stanton \& Wiley, 2011). So, it is logical to assume that the attitude of the Brazilian consumer towards organic food influences the purchase intention of this product. Thus, there would be a positive relationship between consumers' attitudes to organic food and their intention to purchase the product.

$\mathbf{H}_{3}$ : The attitude towards organic food affects positively the purchase intention of these foods.

Finally, taking into account the literature background on TPB and organic consumption, and the role that attitude usually plays, mediating the relationship between the independent variable and the dependent variable (Al-Swidi et al., 2014; Bagozzi et al., 1989; Katt \& Meixner, 2020; Kuran \& Mihic, 2014; Meyer-Hofer et al., 2015; Tarkiainen \& Sundqvist, 2005; 
Watanabe, Alfinito \& Hamza, 2020; Yadav \& Pathak, 2016;), it assumes that as the individual's attitude becomes more favorable to the consumption of organic food, their perceptions regarding the pro-organic food lifestyle begin to have more influence on the purchase intention.

H4: The influence of OFRL toward purchase intentions is mediated by attitude towards organic food.

\section{Methods}

According to the hypotheses, and the research model (Figure 1), to study the effect of OFRL toward attitude and purchase intention of organic food an online survey was carried out with 651 consumers of organic food.

\subsection{Participants and data collection procedure}

The surveys were undertaken from May 5 to May 30, in 2019, using Google.forms to collect the answers. The population of interest to reach the objectives proposed by this study were Brazilian consumers with different levels of consumption of organics. As there is no sampling structure of organic food consumers in Brazil, there was no control over the sampling selection. The filter question referred to the age of the interviewees, since all participants should be older than 18 years old and be interested in participating in the study.

For the sample calculation, following the recommendations of Ringle, Silva and Bido (2014), the $G^{*}$ Power 3.1 software was used, adopting the specifications determined by Cohen (1988), with an Average Effect Size (0.15) and Power of 0.80. From these premises, the sample calculation resulted in a minimum number of 68 respondents, sufficient to detect the desired effects of Structural Equation Modeling with the Partial Least Square (PLS). In total, 669 people were selected by nonprobability sampling method, resulting 651 valid questionnaires.

Also, to evaluate possible biases created in the data collection process, we calculate the Common Method Variance (CMB) by two ways: a) Harman's single factor test: it is performed by calculating an exploratory factor analysis without rotation and with a single factor. The extracted variance must be less than $40 \%$ ("to be even more conservative". See Hair et. al. 2019, p. 744) and b) in SEM-PLS by including a second order variable (method) linked with the observed variables and with the original constructs. This method was suggested by Podsakoff et al. (2003) and was implemented by Liang et al. (2007). In the analysis of the results, we must compare the AVEs average values of all the originals with all due to the method. 


\subsection{Measures and procedures}

The scale item used in this study were adapted from previously validated scales in other contexts (Grunert, Brunso, \& Bisp, 1995; Konuk, 2017; Nuttavuthisit \& Thøgersen, 2017). The application uses a scale type Likert (see Appendice 3) with seven points for agreement/disagreement, where 1 (one) stands for total disagreement and 7 (seven) represents total agreement. The validation in Portuguese of measurement scales were based on a series of steps (DeVellis, 2003; Hair Jr et al., 2019a): 1) clear definition of each construct; 2) literature review searching for validated sacales with items measuring the same constructs; 3) adopted scales were submitted to the translation and back-translation technique; 4) theoretical or face validation - the research instrument was evaluated and validated by three specialists in the marketing area, who contributed to the adjustments of the sentences and the assessment of their fit in the respective constructs proposed by the research; 5) semantic validation with possible respondents (pre-tested with 40 respondents from target sample), by face-to-face interview; 6) statistical validation by confirmatory composite analysis (CCA) associated with modeling partial least squares structural equations (PLS-SEM). The final scale, after the adjustment of the model is in the Appendix.

After the testing and evaluation of the internal consistency of the proposed model by Structural Equation Modeling (SEM) using the SmartPLS 2.0 software, the analysis and evaluation of the structural model were done, demonstrating how these latent variables are related to each other (Bido \& Silva, 2019). The results of the study are presented further.

\section{Results}

\subsection{Sample characteristics}

After data screening, by the missing cases verification, the Mahalanobis test was done. The results pointed out less than $3 \%$ of outliers (19 respondents), so the decision was the maintenance of the respondents. Also, the CMB was evaluated. As a result, was obtained for the first method an explained variance value of $30.9 \%$, indicating that the data can be considered without CMB. In the second method (see Table 1), it could be concluded that the AVE (global) stroke of the original model explained $65.7 \%$ of the data and the AVE (global) due to the method explained only $0.9 \%$. Thus, it is unlikely that the data collection method generated bias.

Also, the Mardia PK test was performed on the Lisrel 8.8 software. The test based on the chi-square distribution (skewness and kurtosis) indicated p-value less than .0001. This indicates that the data violate the assumption of multivariate normality required by the SEM 
covariance based. Thus it was used in SEM-PLS (correlation based), which does not need this assumption (Hair et al., 2014).

\section{Table 1}

Factor Loads, Cummunalities and AVEs For the Original Model and the Model Due to the Method

\begin{tabular}{|c|c|c|c|c|c|c|}
\hline Variable & $\begin{array}{c}\text { Original } \\
\text { model load }\end{array}$ & Communalities & AVE & $\begin{array}{c}\text { Due the } \\
\text { method } \\
\text { load }\end{array}$ & Communalities & AVE \\
\hline IPI_1 & .718 & .516 & & .082 & .007 & \\
\hline IPI_2 & .838 & .702 & .69 & -.001 & $<.0001$ & .004 \\
\hline IPI_3 & .928 & .861 & & -.073 & .005 & \\
\hline $\mathrm{HLT}_{-} 1$ & .858 & .736 & & -.037 & .001 & \\
\hline HLT_2 & .654 & .428 & .673 & .204 & .042 & .025 \\
\hline $\mathrm{HLT}_{2} 3$ & .925 & .856 & & -.177 & .031 & \\
\hline PRC_1 & .827 & .684 & & -.042 & .002 & \\
\hline PRC_2 & .742 & .551 & .643 & .087 & .008 & .004 \\
\hline $\mathrm{PRC}_{2} 3$ & .833 & .694 & & -.043 & .002 & \\
\hline CNV_1 & .837 & .701 & & -.034 & .001 & \\
\hline CNV_2 & .796 & .634 & .613 & $<.0001$ & $<.0001$ & .001 \\
\hline CNV_3 & .711 & .506 & & .038 & .001 & \\
\hline $\mathrm{ATT}_{-1}$ & .795 & .632 & & -.061 & .004 & \\
\hline ATT_2 & .826 & .682 & & -.155 & .024 & \\
\hline ATT_3 & .761 & .579 & .558 & -.068 & .005 & .018 \\
\hline $\mathrm{ATT}_{-4}$ & .784 & .615 & & .031 & .001 & \\
\hline $\mathrm{ATT}_{-} 7$ & .532 & .283 & & .235 & .055 & \\
\hline PCI_1 & .883 & .78 & & -.038 & .001 & \\
\hline PCI_2 & .809 & .654 & .764 & .09 & .008 & .004 \\
\hline PCI_3 & .927 & .859 & & -.055 & .003 & \\
\hline Mean & & .648 & .657 & & .010 & .009 \\
\hline
\end{tabular}

Source: Research results.

Regarding the participants' characteristics (Appendix 1), the sample was composed primarily of women $(73.6 \%)$ and the age groups between 25 and 54 years old correspond to about $66.36 \%$ of the sample. In addition, in educational terms, it is observed that most respondents have at least Higher Education (89.86\%) and approximately $63.44 \%$ of the sample is engaged in some paid professional occupation. Considering the organic food purchase habits, $96 \%$ are organic consumer, $48 \%$ indicated buying organic food at least once a week (the other 
$52 \%$ in a lower frequency), $49 \%$ stated buying food from supermarkets, specialized stores or directly from the producer and $41 \%$ indicated they buy organic products at open markets.

Despite the methodological meticulousness adopted in this research, it presents limitations: non-probabilistic convenience sampling does not allow the generalization of the results, neither the making of inferences for the entire population, however, as the objective of this research is to evaluate as possible interdependence relationships between the variables studied, a sampling technique for convenience is applicable (Hair et al., 2019).

The sample presents a concentration in gender-female consumers. Considering that there was not sampling control, the sample concentration on female-gender could be another limitation of the research. However, the concentration corroborates previous research (Barbosa, 2007; Medeiros 2017; Vasques, Clays \& Silva, 2008) which justify the concentration through cultural reasons: women are more attentive to issues of family health, well-being, and healthy habits and even because women continue to be responsible for feeding everyone residents of the house, from the purchase, choice or preparation of food consumed by the family (Bernardes et al. 2016; Porto \& Nardi, 2019).

Considering the organic food purchase habits, 95.7\% da amostra consome ou já consumiu alimentos orgânicos, $48 \%$ indicated buying organic food at least once a week (the other $52 \%$ in a lower frequency), $49 \%$ stated buying food from supermarkets, specialized stores or directly from the producer and $41 \%$ indicated they buy organic products at open markets.

\subsection{Data analysis: measurement model}

In order to test construct validity, convergent and discriminant validity of the constructs were analyzed. Convergent validity was analyzed using the Average Variance Extracted (AVEs). In the first round of the PLS Algorithm, the analysis revealed that only the VL Atitude had items with values $<.50$. In this case, by eliminating the VO's with the lowest factor loads $(<.50)$, in VL Atitude: ATT_5 (.142), ATT_6 (.488), ATT_8 (.068), ATT_9 (.069) e ATT_10 (.293) and running the program again, the quality criterion was reached, with all AVEs> .50, ensuring convergent validity (Hair Jr et al., 2014). The final results are shown in table 2. 
Table 2

Validity and Reliability Analysis

\begin{tabular}{lcccccc}
\hline Discriminant Validity (Fornell-Larcker criterion) & $\mathbf{1}$ & $\mathbf{2}$ & $\mathbf{3}$ & $\mathbf{4}$ & $\mathbf{5}$ & $\mathbf{6}$ \\
\hline 1. Importance of product information & $\mathbf{. 8 3 1}$ & & & & & \\
2. Price criteria & .347 & $\mathbf{. 8 0 0}$ & & & & \\
3. Health & .595 & .262 & $\mathbf{. 8 1 0}^{*}$ & & & \\
4. Convenience & .239 & .112 & .280 & $\mathbf{. 7 8 2}^{*}$ & & \\
5. Attitude & .316 & .206 & .492 & .104 & $\mathbf{. 7 3 6}$ & \\
6. Purchase Intention & .469 & .211 & .617 & .118 & .638 & $\mathbf{. 8 7 2}$ \\
& & & & & & \\
Cronbach's Alpha (CA) & .775 & .721 & .737 & .683 & .790 & .843 \\
Composite Reliability (CR) & .870 & .842 & .851 & .825 & .855 & .905 \\
Average Variances Extracted (AVE) & .691 & .640 & .656 & .612 & .542 & .761 \\
\hline
\end{tabular}

"Root Square of the AVEs

Source: Research results.

To evaluate the discriminant validity, that indicates the extent to which constructs or latent variables are independent of one another (Hair Jr et al., 2014) were used the criteria of Chin (1998) and by the criterion of Fornell and Larcker (1981). The evaluation of the discriminant validity (DV) using the the Fornell and Larcker's criterion (1981) the discriminant validity was proved: the square roots of the AVE values of each construct are greater than the correlations (of Pearson) between constructs (or latent variables), as shown in Table 2. It stands out is the correlation value of intencion-attitude was high and close to the variance extracted root square value (.638 and .736 respectively). But the Chin (1998) criterion, proved that the latent constructs or variables are different from each other, since all the indicators (or observable variables) presented higher factor loads in their respective VL (or constructs) than in others, all VO's of Attitude and Purchase Intention was preserved (Appendice 2).

The analysis of internal consistency - Cronbach's alpha (CA) and Composite Reliability (CR) -, showed that the sample is free of bias and the answers, as a whole, are reliable, because the values of CA are greater than .60 and the CR values are greater than .70, (Hair Jr et al., 2014), as shown in Table 2.

\subsection{Data analysis: structural equation model}

After the measurement model analysis and the necessary adjustments, the adjusted model was confirmed. Figure 2 presents the structural model with the values of the correlations 
between VO and VL; shows the value of $\mathrm{R}^{2}$ and shows the path coefficient of linear regression between VLs.

\section{Figure 2}

\section{Structural Equation Modeling: Adjusted Research Model}

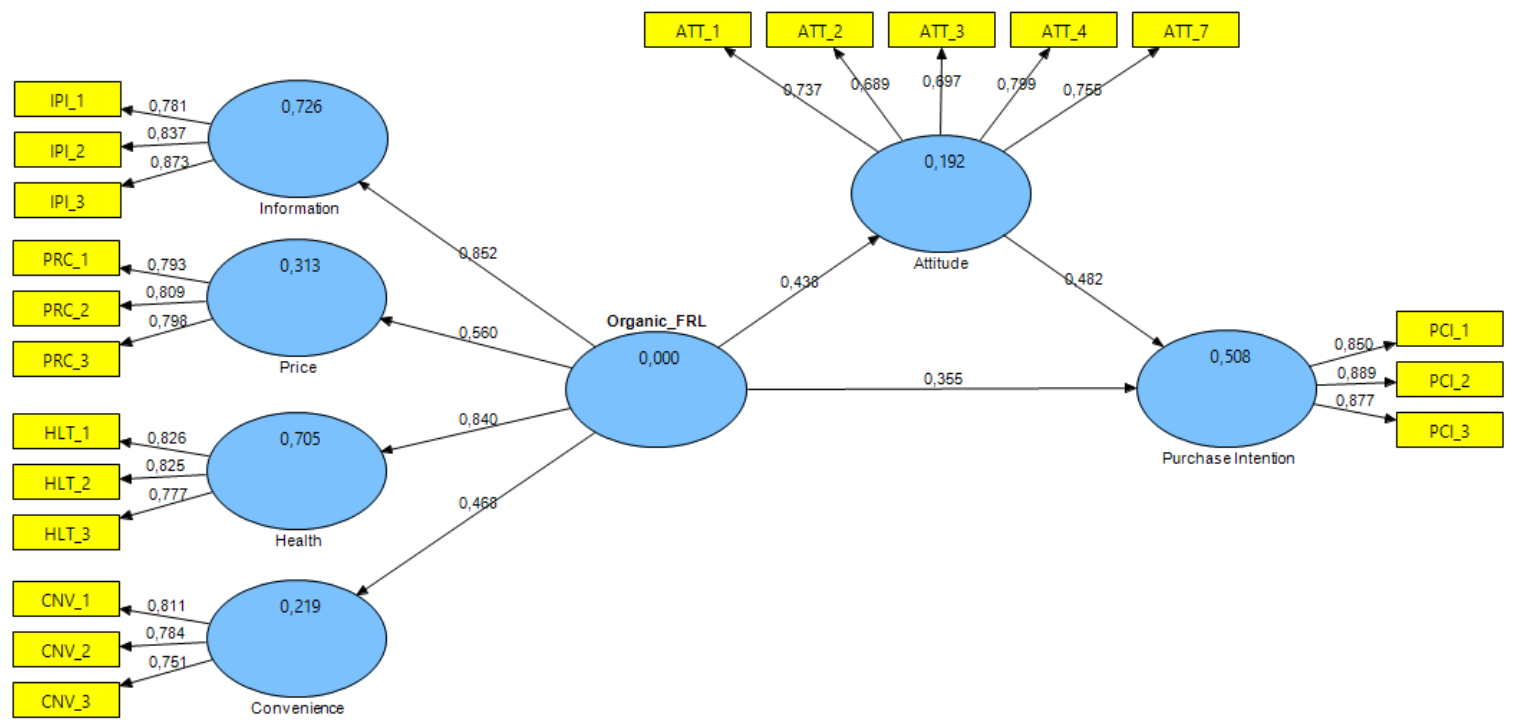

Source: Research results.

The adjusted model presents good structural quality: $\mathrm{R}^{2}$ with values of $19 \%$ (attitude) and $51 \%$ (purchase intention), as shown in figure 2. For research carried out in the areas of social and behavioral sciences, it is suggested R Square coefficients equal to $13 \%$ be classified as a medium effect and $26 \%$ as a large effect (Cohen, 1988).

Predictive validity, an indicator of the model's quality of fit, was assessed using the Stone-Geisser indicator $\left(\mathrm{Q}^{2}\right)$. The values obtained are greater than zero for all variables (Hair

et al, 2014), so the quality of adjustment was proven. The analysis of the effect size, using the Cohen Indicator $\left(\mathrm{f}^{2}\right)$, showed that all constructs are useful for the model adjustment, as they all present values indicated as small $(\geq 2 \%)$, medium $(\geq 15 \%)$ and great effect $(\geq 35 \%)$, as shown in table 3.

\subsection{Data analysis: hypothesis test}

The validity of the relationships (correlations and regressions) between the variables was performed through resampling (bootstraping) with 5.000 subsamples. The reference value for analysis is $\mathrm{t} \geq 1.96$ and the technique is the Student's $\mathrm{t}$ test (Hair Jr et al., 2014). In all 
relationships, the values were greater than $1.96(\mathrm{p}<.001)$, so the correlations and regression coefficients are significant. The path coefficients values ( $\Gamma$ or $\beta-$ angular coefficients of regression lines) ranged between .355 and .482 , indicating positives and strong relationship (Cohen, 1988) (table 3).

\section{Table 3}

Hypothesis Test

\begin{tabular}{|c|c|c|c|c|c|}
\hline Hypothesis & & $\begin{array}{c}\text { Path } \\
\text { coefficient }\end{array}$ & $\mathbf{f}^{2}$ & p-value & Conclusion \\
\hline ORL $\square$ PCI & $\mathrm{H} 1(+)$ & .355 & 207 & $<.001$ & supported \\
\hline OFRL $\square$ ATT & $\mathrm{H} 2(+)$ & .438 & .238 & $<.001$ & supported \\
\hline ATT $\square$ PCI & $\mathrm{H} 3(+)$ & .482 & .382 & $<.001$ & supported \\
\hline OFRL $\square$ ATT $\rightarrow$ PCI & $\mathrm{H} 4(+)$ & .566 & - & $<.05$ & supported \\
\hline
\end{tabular}

Source: Research results.

Finally, to confirm the mediation expressed in hypotheses 4, Sobel's test was performed. The results point out that the mediator variable significantly carries the influence of the independent variable to the dependent variable; i.e., the indirect effect of the OFRL on the purchase intettion (PCI) mediated by atittude (ATT) is significant [total effect: .566; Sobel's test statistic: 9.23 ; relationship is significant $(\mathrm{p}<.05)$ ]. It means that attitude improves the effect of OFRL on purchase intention.

\section{Discussion}

The results achieved with SEM-PLS, will be discussed and expanded below. First, an analysis of the direct relationships between independent and dependent variables was performed. The second step was to compare the direct and indirect effects, analyzing the mediation of the OFRL-ATT- PCI relationship. Given its importance in the composition of the second-order latent variable, the relationships between the second-order construct OFRL and its four dimensions were also tested and analyzed.

The research provided evidence that lifestyle explains organic consumption. The model explained $19 \%$ of the ATT variance and $51 \%$ of the PCI variance. The analysis of OFRL as a predictor of ATT and PCI of organic food was statistically confirmed, corroborating previous studies that indicate that lifestyle, including food-related lifestyle, defines the pattern of 
consumption that reflects an individual's choices on how to spend their time and money (Hughner et al., 2007; Pérez-Cueto, et al., 2010).

The hypothesis H1 suggests that OFRL affects the intention to purchase organic food. The direct relationship between the two variables has a t-value of $10.351, \mathrm{p}<.001$ and a path coefficient of .355 , indicating a significant relationship between the constructs. It means OFRL is a good predictor of PCI. Corroborating previous studies (Vera et al., 2016; Oroian et al., 2017; Rana \& Paul, 2017; Thøgersen, 2017), this work brings empirical evidence of that relationship. The results suggest that by encouraging a healthy lifestyle there may be an indirect stimulus to the consumption of organic foods.

The H2 was confirmed ( $\mathrm{p}<.001$, $\mathrm{t}$-value of 11.975 and a path coefficient of .438). So, the organic food-related lifestyle has a positive effect on the attitude toward organic food, and is stronger than the effect on intention. The results corroborate previous studies (Carfora et al., 2019; Watanabe, Alfinito \& Hamza, 2020), confirm the role of lifestyle in the consumption of organic food.

Hypothesis H3 establishes that the ATT towards organic food affects the intention to purchase these foods. The relationship between the two variables has a t-value of 14.471 and a path coefficient of .482, indicating a significant relationship. The Hypothesis H3 was confirmed, it also indicates that the ATT affects the intention to purchase organic food, corroborating the results of previous studies (Al-Swidi et al., 2014; Katt e Meixner, 2020; Kuran \& Mihic, 2014; Meyer- Hofer et al., 2015; Watanabe, Alfinito e Hamza, 2020; Tarkiainen \& Sundqvist, 2005; Yadav e Pathak, 2016). In other words, the more favorable the consumers' ATT towards organic food, the greater their PCI.

Finally, the mediation expressed in hypotheses H4 was confirmed, corroborating the literature (Bagozzi, 1989). The Sobel's test was performed. The results point out that the mediator variable significantly carries the influence of the independent variable to the dependent variable; i.e., the indirect effect of the OFRL on the PCI mediated by ATT is significant and complementary (total effect: .566; Sobel's test statistic: 9.23; relationship is significant $(\mathrm{p}<.05)$. It means that the mediation role played by ATT in the relationship between OFRL and PCI is positive and significant and improves the importance of organic food-related lifestyle as a predictor of purchase intention.

The literature presents that develop an awareness of the benefits of organic food, especially those related to health, given the growing concern of consumers with issues related to this aspect, tend to reinforce the attitude towards these foods (Ergönül \& Ergönül, 2015; 
Oroian, et al., 2017). In this research, there is evidence that attitude is an important predictor of purchase intention of organic food, and perform a mediator role between organic food-related lifestyle and purchase intention.

Therefore, considering the direct effect of OFRL on PCI and the indirect effect, i.e., when mediated by the ATT, it can be said that the OFRL is a good predictor of PCI (total effect: .566). This effect happens partially directly, through the influence of OFRL on the PCI (H1), and partially through the indirect path OFRL-ATT- PCI (H4). Both effects complement each other, so that, from the moment beliefs favor the formation of favorable attitudes towards organic consumption, the effect of lifestyle on purchase intention is enhanced by affecting both directly and indirectly.

The relationships between the second-order OFRL construct and its four dimensions were also tested and analyzed. The relationships between OFRL and information on the product $(.852 ; \mathrm{p}<.01)$, price sensitivity $(.560 ; \mathrm{p}<.01)$ and health concern $(.840 ; \mathrm{p}<.01)$ and convenience $(.468 ; \mathrm{p}<.01)$ were all significant at $1 \%$, but with different magnitudes. It is observed that some of the dimensions used to compose the OFRL are more relevant to impact the attitude and intention to consume organic food than others. Thus, the results achieved with the operational variables will be discussed in comparison with the literature.

The variable "importance of product information" presented the bigger association with the OFRL (the highest path coefficient $=.852$; Composite Reliability $(C R)=.870$ ). The product information is capable of identifying it as an organic food, in addition to allowing comparisons to be made between organic and non-organic. Its importance for the consumption of the product is vital. This result corroborates previous studies which indicate that consumers associate the consumption of organic food with a high degree of involvement with the food experience and a growing interest in all aspects of food purchase, mainly with the product information (Fang \& Lee, 2009; Grunert, Brunso, \& Bisp, 1993; Grunert, Brunso, \& Bisp, 1995; Ryan et al., 2004). Moreover, food labeling is an important strategies to assist consumers during the food choice process and can be an ally for organic market development (Gottschalk \& Leistner, 2012; Lim, Yong \& Suryadi, 2014; Prada, Garrido, \& Rodrigues, 2017; Sangkumchaliang \& Huang, 2012).

The health dimension showed the greatest association with the OFRL (path coefficient $=.840 ; \mathrm{CR}=.851)$. Along with the "importance of product information", the "health" dimension helps in the formation of a food-related life style capable of predicting the attitude and intention to purchase organic food. That is because health-conscious consumers tend to 
demonstrate a greater preference for these foods (Hemmerling, Hamm \& Spiller, 2015; Oroian, et al., 2017; Rödiger \& Hamm, 2015).

The variable "price sensibility" produced a path coefficient of .560 and a CR of .842 . Price criteria is a key variable since, according to the literature, the price plays a significant role in the decision-making process and express one of the most relevant barriers to organic food consumption (Aertsens, Verbeke, Mondelaers, \& Huylenbroeck, 2009; Rödiger \& Hamm, 2015; Shin, 2018).

The scale adopted measures the search for promotions and the attention given to possible price variations. At first glance, it could be assumed that such behaviors would not be compatible with the consumption of organic food. However, it can suggest a behavioral trend, named "trading up/trading down", which leads middle class consumers to seek for cheaper products or brands in low engagement categories, so they can spend more on products and brands in high engagement categories (Silverstein, Fiske \& Butman, 2008).

That trend would explain that it is possible to be price sensible for some categories and not to be for another one. Based on that trend, the similar behavior in the consumption of organic food could be hypothesized. So, the organic consumer could be engaged with food and willing to pay more to have healthy food. Thus, the behavior of seeking promotions and paying attention to price variations could indicate the possibility of making substitutions, for example, spending less on household cleaning items, to spend more on healthier foods. Therefore, it cannot be concluded that the price criterion is a barrier to organic consumption.

Finally, the dimension "convenience", whose scale measured convenience in food preparation, presented the lowest association with OFRL (path coefficient $=.468 ; \mathrm{CR}=.825$ ). Even treated in a reverse way, as it presents a sense opposite to the consumption of organic food, the convenience scale was not very efficient as a lifestyle dimension to shape the attitude and intention to purchase organic food.

\section{Conclusion}

The main objet of this article was to analyze the effect of organic food-related lifestyle determinants on the the attitude and purchase intention towards organic food for Brazilian consumers. The results presented evidence that the organic food-related lifestyle, mediated or not by attitude, are a good predictor of the intention to buy organic food. There are a main theoretical contributions that emerged from this study: the originality of the proposal. The study is the first to propose a multidimensional construct to measure the organic food related lifestyle 
in the Brazilian context and their impact in the attitude and purchase intention of that food, introducing a conceptual structure and modeling the constructs, through structural equation.

In addition, the results confirmed the relationship between the attitude and the purchase intention showing that the more favorable the consumer's attitude towards organic food, the greater their purchase intention. Thus, stimulating consumption also depends on the awareness of the benefits of organic food, which tend to reinforce the attitude towards these foods. In turn, the theory indicates that the awareness made possible by communicative processes is a component of the formation of attitudes, which reinforces the conclusion before. The results highlighted the importance of information about the product in the process of decision and purchase of organic food, corroborating previous studies.

Thus, the paper provides managerial implications revealing the fundamental role of information in the organic food-related lifestyle and in the formation of a attitude towards the consumption of organics, within the Brazilian context. Expanding the scope of these results, it can be inferred that in the Brazilian market giving information about the benefits of organic food is even more important because the organic segment is still a niche and the consumer has more doubts, than certainties about the production process and the advantages of organic food. Thus, the results suggest a great opportunity for the chain to unite and work on institutional communication more effectively to create awareness about health benefits. It is probable the more Brazilian consumers perceive the health benefits of organic food more favorable they will be on consumption of that food. This finding is important to stimulate the growth of the organic food market in Brazil, which is still embryonic.

Despite the methodological care and meticulousness adopted in conducting the research, it has limitations: its non-probability of convenience sampling technique, preventing the generalization of results. In addition, the sample has a female-gender consumers concentration, which seems to reflect the profile of the organic buyer.

This paper suggests that future studies analyze, comparatively, different categories of organic food, in order to assess whether the impact of the dimensions of organic food related lifestyle, especially importance of product information and health, on the attitude and the intention of purchase are repeated in all types of food or if they vary by category. In that context, another relevant aspect is to assess whether consumers have different levels of attitude and purchase intention in relation to the different product macro categories, focusing mainly on the distinction between fresh and processed organic food. It is possible suggested that future 
research uses more heterogeneous samples, allowing to identify the stability of the observed results.

\section{References}

ABRAS. Associação Brasileira de Supermercados Setor de orgânicos cresce $30 \%$ no Brasil em 2020. (10 fev 2021). https://www.abras.com.br/clipping/geral/72392/setor-deorganicos-cresce-30-no-brasil-em-2020.

Achilleas, K., \& Anastasios, S. (2008). Marketing aspects of quality assurance systems: the organic food sector case. British Food Journal, 110(8), pp. 829-839.

https://doi.org/10.1108/00070700810893359

Aertsens, J., Verbeke, W., Mondelaers, K., \& Huylenbroeck, G. V. (2009). Personal determinants of organic food consumption: a review. British Food Journal, 111(10), pp. 1140-1167. https://doi.org/10.1108/00070700910992961

Ajzen, I. (1991). The theory of planned behavior. Organizational Behavior and Human Decision Processes, 50, pp. 179-211. https://doi.org/10.1016/0749-5978(91)90020-T

Ajzen, I., \& Fishbein, M. (1973). Attitudinal and normative variables as predictors of specific behavior. Journal of Personality and Social Psychology, 27, pp. 41-57.

https://doi.org/10.1037/h0034440

Al-Swidi, A., Huque, S. M., Hafeez, M. H., \& Shariff, M. M. (2014). The role of subjective norms in theory of planned behavior in the context of organic food consumption. British Food Journal, 116(10), pp. 1561-1580. https://doi.org/10.1108/BFJ-05-2013-0105

Anderson Jr, W. T., \& Golden, L. L. (1984). Lifestyle and psychographics: A critical review and recommendation. Advances in consumer research, 11(1), pp. 405-411.

Aschemann-Witzel, J., \& Aagaard, E. M. (2014). Elaborating on the attitude-behaviour gap regarding organic products: young Danish consumers and in-store food choice.

International Journal of Consumer Studies, 38(5), pp. 550-558.

https://doi.org/10.1111/ijcs.12115

Barbosa, S. C. et al. Perfil do consumidor e oscilações de preços de produtos agroecológicos. Revista de Pesquisa Agropecuária, Goiânia-GO, v. 41, n. 4, p. 602-609, Out./Dez. 2011. https://doi.org/10.5216/pat.v41i4.11854

Bell, W. (1958), "Social choice, life style, and suburban residence", in Dobriner, W.M. (Ed.), The Suburban Community, G.P. Putnam's Sons, New York, NY, pp. 225-242.

Bagozzi, R.P., Baumgartner, J. and Yi, Y. (1989), "An investigation into the role of intentions as mediators of the attitude-behavior relationship", Journal of Economic Psychology, 10, 35-62. https://doi.org/10.1016/0167-4870(89)90056-1

Bernardes, A. F. M., Silva, C. G., \& Frutuoso, M. F. P. (2016). Alimentação saudável, cuidado e gênero: percepções de homens e mulheres da zona noroeste de Santos-SP. Demetra: Alimentação, Nutrição \& Saúde, 11(3), 559-573. https://doi.org/10.12957/demetra.2016.22334 
Bido, D. S., \& Silva, D. (2019). SmartPLS 3: specification, estimation, evaluation and reporting. Administração: Ensino e Pesquisa, 20(2), pp 465-513. https://doi.org/10.1305 8/raep.2 019.v20n2 .1545

Britwum, K., Bernard, J. C., \& Albrecht, S. E. (2020) Importance influence beliefs in organic food attributes? Food Quality and Preference, pp. 2411-2502.

https://doi.org/10.1016/j.foodqual.2020.104056

Capps, O., Tedford, J. R., \& Havlicek, J. (1985). Household Demand for Convenience and Nonconvenience Foods. American Journal of Agricultural Economics, 67, pp. 862-869. https://doi.org/10.2307/1241827

Carfora, V., Cavallo, C., Caso, D., Del Giudice, T., De Devitiis, B., Viscecchia, R., \& Cicia, G. (2019). Explaining consumer purchase behavior for organic milk: Including trust and green self-identity within the theory of planned behavior. Food Quality and Preference, 76, 1-9. https://doi.org/10.1016/j.foodqual.2019.03.006

Chen, J., \& Lobo, A. (2012). Organic food products in China: determinants of consumers' purchase intentions. The International Review of Retail, Distribution and Consumer Research, 22(3), pp. 293-314. . https://doi.org/10.1080/09593969.2012.682596

Chin, W. W. (1998). The partial least squares approach for structural equation modeling. Modern methods for business research. Mahwah: Lawrence Erlbaum Associates Publishers.

Chryssochoidis, G. (2000). Repercussions of consumer confusion for late introduced differentiated products. European Journal of Marketing, 34(5/6), pp. 705-722. https://doi.org/10.1108/03090560010321992

Cohen, J. (1988). Statistical Power Analysis for the Behavioral Sciences. New York: Psychology Press.

Devellis, R. F. (2003). Scale development: theory and applications. Thousand Oaks: Sage Publications, 2003.

Ergönül, B., \& Ergönül, P. G. (2015). Consumer motivation for organic food consumption. Emirates Journal of Food and Agriculture, 27(5), pp. 416-422. https://doi.org/10.9755/ejfa.2015.04.034

Essoussi, L. H., \& Zahaf, M. (2008). Decision making process of community organic food consumers: an exploratory study. Journal of Consumer Marketing, 25(2), pp. 95-104. https://doi.org/10.1108/07363760810858837

Fang, C. H., \& Lee, H. J. (2009). Food-related lifestyle segments in Taiwan: application of the food-related lifestyle instrument. American Journal of Applied Sciences, 6(12), pp. 2036-2042. https://doi.org/10.3844/ajassp.2009.2036.2042

Fornell, C., \& Larcker, D. F. (1981). Evaluating structural equation models with unobservable variables and measurement error. National Institute of Industrial Engineering. Mumbai. 
Gerrard, C., Janssen, M., Smith, L. H., \& Padel, S. (2013). UK consumer reactions to organic certification logos. British Food Journal, 115(5), pp. 727-742.

https://doi.org/10.1108/00070701311331517

Goetzke, B. I., \& Spiller, A. (2014). Health-improving lifestyles of organic and functional food consumers. British Food Journal, 116(3), 510-526. https://doi.org/10.1108/BFJ-032012-0073

Gonzalez, J. A. (2012). World economic crisis impact on organic products consumption: Costa Rica, 2009. British Food Journal, 114(1), pp. 5-18. https://doi.org/10.1108/00070701211197338

Gottschalk, I., \& Leistner, T. (2012). Consumer reactions to the availability of organic food in discount supermarkets. International Journal of Consumer Studies, 37(2), pp. 136-142. https://doi.org/10.1111/j.1470-6431.2012.01101.x

Grunert, K. G. (1993). Towards a concept of food-related lifestyle. Appetite, 21, pp. 151-155. https://doi.org/10.1016/0195-6663(93)90007-7

Grunert, K. G., Brunsø, K., \& Bisp, S. (1993). Food-related lifestyle: development of a crossculturally valid instrument for market surveillance. Århus, Denmark: MAPP.

Grunert, K. G., Brunsø, K., \& Bisp, S. (1995). Food-related life style in Great Britain. Aarhus: Mapp Project.

Gutman, J. (1982). A means-end chain model based on consumer categorization processes. Journal of marketing, 46(2), 60-72. https://doi.org/10.2307/3203341

Hair, J.F., Black, W.C., B.J., \& Anderson, R.E. (2019). Multivariate data analysis. 9th ed. Hampshire: Cengage Learning.

Hair, J. F., Gabriel, M. L., da Silva, D., \& Junior, S. B. (2019a). Development and validation of attitudes measurement scales: fundamental and practical aspects. RAUSP Management Journal, 54(4), 490-507. https://doi.org/10.1108/RAUSP-05-2019-0098

Hair Jr, J. F., Hult, G. T., Ringle, C. M., \& Sarstedt, M. A. (2014). Primer on Partial Least Squares Structural Equation Modeling (PLS-SEM). Thousand Oaks: Sage Publications.

Harper, G. C., \& Makatouni, A. (2002). Consumer perception of organic food production and farm animal welfare. British Food Journal, 104(3/4/5), 287-299.

https://doi.org/10.1108/00070700210425723

Hasselbach, J. L., \& Roosen, J. (2015). Consumer heterogeneity in the willingness to pay for local and organic food. Journal of Food Products Marketing, 21(6), 608-625. https://doi.org/10.1080/10454446.2014.885866

Havighurst, R. J., \& Feigenbaum, K. (1959). Leisure and life-style. American Journal of Sociology, 64(4), 396-404. https://doi.org/10.1086/222500 
Hemmerling, S., Hamm, U., \& Spiller, A. (2015). Consumption behaviour regarding organic food from a marketing perspective: a literature review. Organic Agriculture, 5(4), pp. 277 313. https://doi.org/10.1007/s13165-015-0109-3

Henseler, J., \& Sarstedt, M. (2013). Goodness-of-fit indices for partial least squares path modeling. Computational statistics, 28(2), 565-580. https://doi.org/10.1007/s00180-0120317-1

Homburg, C., Koschate, N., \& Hoyer, W. D. (2005). Do satisfied customers really pay more? A study of the relationship between customer satisfaction and willingness to pay. Journal of Marketing, 69(2), 84-96. https://doi.org/10.1509/jmkg.69.2.84.60760

Hughner, R. S., McDonagh, P., Prothero, A., Shultz, C. J., \& Stanton, J. (2007). Who are organic food consumers? A compilation and review of why people purchase organic food. Journal of Consumer Behaviour, 6, 94-110. https://doi.org/10.1002/cb.210

Janssen, M. (2018). Determinants of organic food purchases: Evidence from household panel data. Food Quality and Preference, 68, 19-28. https://doi.org/10.1016/j.foodqual.2018.02.002

Katt, F., \& Meixner, O. (2020). A systematic review of drivers influencing consumer willingness to pay for organic food. Trends in Food Science \& Technology, 100, 374-388. https://doi.org/10.1016/j.tifs.2020.04.029

Konuk, F. A. (2017). Price fairness, satisfaction, and trust as antecedents of purchase intentions towards organic food. Journal of Consumer Behaviour, 17(2), 141-148. https://doi.org/10.1002/cb.1697

Kuran, L. M., \& Mihic, M. (2014). Applying the theory of planned behavior in the purchase of organic food. Trziste, 26, 179-197.

Liang, H., Saraf, N., Hu, Q., \& Xue, Y. (2007). Assimilation of enterprise systems: the effect of institutional pressures and the mediating role of top management. MIS quarterly, 59-87. https://doi.org/10.2307/25148781

Lim, W. M., Yong, J. L., \& Suryadi, K. (2014). Consumers' perceived value and willingness to purchase organic food. Journal of Global Marketing, 27(5), 298-307. https://doi.org/10.1080/08911762.2014.931501

McBroom, W. H., \& Reed, F. W. (1992). Towards conceptualization of Attitude-Behavior Consistency. Social Psychology Quarterly, 55(2), 205-216. https://doi.org/10.2307/2786946

Medeiros, B. E., Marconato, T., \& de Souza, A. E. (2017). Estudo bibliométrico sobre a motivação para o consumo de produtos orgânicos. Revista Cadernos de Economia, 21(38), 74-88.

Meyer-Hofer, M. V., Olea-Jaik, E., Padilla-Bravo, C. A., \& Spillera, A. (2015). Mature and Emerging Organic Markets: Modelling Consumer Attitude and Behaviour With Partial Least Square Approach. Journal of Food Products Marketing, 21(6), 626-653. https://doi.org/10.1080/10454446.2014.949971 
Mondelaers, K., Verbeke, W., \& Huylenbroeck, G. V. (2009). Importance of health and environment as quality traits in the buying decision of organic products. British Food Journal, 111(10), 1120-1139. https://doi.org/10.1108/00070700910992952

Nuttavuthisit, K., \& Thøgersen, J. (2017). The importance of consumer trust for the emergence of a market for green products: The case of organic food. Journal of Business Ethics, 140(2), 323-337. https://doi.org/10.1007/s10551-015-2690-5

Oroian, C. F., Safirescu, C. O., Harun, R., Chiciudean, G. O., Arion, F. H., Muresan, I. C., \& Bordeanu, B. M. (2017). Consumers' attitudes towards organic products and sustainable development: a case study of Romania. Sustainability, 9(9), 1559-1573. https://doi.org/10.3390/su9091559

Paul, J., \& Rana, J. (2012). Consumer behavior and purchase intention for organic food. Journal of Consumer Marketing, 29(6), 412-422. https://doi.org/10.1108/07363761211259223

Pérez-Cueto, F. J., Verbeke, W., De Barcellos, M. D., Kehagia, O., Chryssochoidis, G. S., \& Grunert, K. (2010). Food-related lifestyles and their association to obesity in five European countries. Appetite, 54(1), 156-162. https://doi.org/10.1016/j.appet.2009.10.001

Piqueras-Fiszman, B., \& Spence, C. (2015). Sensory expectations based on product-extrinsic food cues: An interdisciplinary review of the empirical evidence and theoretical accounts. Food Quality and Preference, 40, 165-179. https://doi.org/10.1016/j.foodqual.2014.09.013

Plummer, J. T. (1974) The concept and application of life style segmentation. Journal of Marketing, 38(1), 33-37. https://doi.org/10.2307/1250164

Podsakoff, P. M., MacKenzie, S. B., Lee, J. Y., \& Podsakoff, N. P. (2003). Common method biases in behavioral research: a critical review of the literature and recommended remedies. Journal of applied psychology, 88(5), 879-903. https://doi.org/10.1037/0021-9010.88.5.879

Porto, B. R., \& Nordi, W. M. (2019). Caracterização de consumidores de alimentos orgânicos: uma pesquisa quantitativa realizada em rede social. Caderno de Ciências Agrárias, 11, 1-9. https://doi.org/10.35699/2447-6218.2019.15926

Prada, M., Garrido, M. V., \& Rodrigues, D. (2017). Lost in processing? Perceived healthfulness, taste and caloric content of whole and processed organic food. Appetite, 114, 175-186. https://doi.org/10.1016/j.appet.2017.03.031

Rana, J., \& Paul, J. (2017). Consumer behavior and purchase intention for organic food: a review and research agenda. Journal of Retailing and Consumer Services, 38, 157-165. https://doi.org/10.1016/j.jretconser.2017.06.004

Rainwater, L., Coleman, R.P., \& Handel, G. (1959), Workingman's wife: her personality, world and life style, New York: Oceana Publ.

Reid, M., Li, E., Bruwer, J., \& Grunert, K. (2001). Food-related lifestyles in a cross-cultural context: comparing Australia with Singapore, Britain, France and Denmark. Journal of Food Products Marketing, 7(4), 57-75. https://doi.org/10.1300/J038v07n04_05 
Ringle, C. M., Silva, D., \& Bido, D. S. (2014). Structural Equation Modeling with the Smartpls. Brazilian Journal Of Marketing, 13(2), 54-71. https://doi.org/10.5585/remark.v13i2.2717

Rödiger, M., \& Hamm, U. (2015). How are organic food prices affecting consumer behaviour? A review. Food Quality and Preference, 43, 10-20. https://doi.org/10.1016/j.foodqual.2015.02.002

Rödiger, M., Plaßmann, S., \& Hamm, U. (2016). Organic consumers' price knowledge, willingness-to-pay and purchase decision. British Food Journal, 118(11). https://doi.org/10.1108/BFJ-04-2016-0164

Ryan, I., Cowan, C., McCarthy, M., \& O'sullivan, C. (2004). Segmenting Irish food consumers using the food-related lifestyle instrument. Journal of International Food \& Agribusiness Marketing, 16(1), pp. 89-114. https://doi.org/10.1300/J047v16n01_06

Sangkumchaliang, P., \& Huang, W. C. (2012). Consumers' perceptions and attitudes of organic food products in Northern Thailand. International Food and Agribusiness Management Review, 15(1), 87-102. https://doi.org/10.22004/ag.econ.120860

Savelli, E., Murmura, F., Liberatore, L., Casolani, N., \& Bravi, L. (2017). Food habits and attitudes towards food quality among young students. International Journal of Quality and Service Sciences, 9(3/4), 456-468. https://doi.org/10.1108/IJQSS-02-2017-0011

Shin, Y. H. (2018). The theory of planned behavior and the norm activation model approach to consumer behavior regarding organic menus. International Journal of Hospitality Management, 69, 21-29. https://doi.org/10.1016/j.ijhm.2017.10.011

Silverstein, M. J., Fiske, N., \& Butman, J. (2008). Trading Up: why consumers want new luxury goods--and how companies create them. New York: Penguin.

Sobel, M. E. (1982). Asymptotic confidence intervals for indirect effects in structural equation models. Sociological Methodology, 13, 290-312. https://doi.org/10.2307/270723

Tarkiainen, A., \& Sundqvist, S. (2005). Subjective norms, attitudes and intentions of finnish consumers in buying organic food. British Food Journal, 107(11), 808-822. https://doi.org/10.1108/00070700510629760

Thøgersen, J. (2017). Sustainable food consumption in the nexus between national context and private lifestyle: A multi-level study. Food Quality and Preference, 55, 16-25. https://doi.org/10.1016/j.foodqual.2016.08.006

Vásquez, S. F., de Souza Barros, J. D., \& da Silva, M. D. F. P. (2008). Agricultura orgânica: caracterização do seu consumidor em Cajazeiras - PB. Revista Verde de Agroecologia e Desenvolvimento Sustentável, 3(1), 152 - 158.

Vera, J. M., Pérez, C. E., Puig, M. A., \& Montero-Vicente, L. (2016). Consumer segmentation based on food-related lifestyles and analysis of rabbit meat consumption. World Rabbit Science, 24(3), 169-182. https://doi.org/10.4995/wrs.2016.4229 
Vukasovic, T. (2013). Attitude towards organic meat: an empirical investigation on West Balkans Countries (WBC) consumers. World's Poultry Science Journal, 69(3), 527-540. https://doi.org/10.1017/S004393391300055X

Watanabe, E. A., Alfinito, S. C., \& Hamza, K. M. (2020). Perceived value, trust and purchase intention of organic food: a study with Brazilian consumers. British Food Journal, 122(4), 1070-1184. https://doi.org/10.1108/bfj-05-2019-0363

Wekeza, S. V.; Sibanda, M. (2019). Factors influencing consumer purchase intentions of organically grown products in shelly centre, port shepstone, South Africa. International journal of environmental research and public health, 16(6), 956.

https://doi.org/10.3390/ijerph16060956

Wirth, F. F., Stanton, J. L., \& Wiley, J. B. (2011). The relative importance of search versus credence product attributes: Organic and locally grown. Agricultural and Resource Economics Review, 40(1), 48-62. https://doi.org/10.1017/S1068280500004512

Yadav, R., \& Pathak, G. S. (2016). Intention to purchase organic food among young consumers: evidences from a developing nation. Appetite, 96, 122-128. https://doi.org/10.1016/j.appet.2015.09.017

Yazdanpanah, M., Forouzani, M., \& Hojjati, M. (2015). Willingness of Iranian young adults to eat organic food: Application of the Health Belief Model. Food Quality and Preference, 41, 75-83. https://doi.org/10.1016/j.foodqual.2014.11.012

Zanoli, R., \& Naspetti, S. (2002). Consumer motivations in the purchase of organic food: A means-end approach. British food journal. 104 (8), 643-653.

https://doi.org/10.1108/00070700210425930 


\section{Appendix 1}

\section{Table 5 - Measurement Scales}

\begin{tabular}{|c|c|c|}
\hline Construct & Label & Item \\
\hline \multirow{3}{*}{$\begin{array}{l}\text { Importance of } \\
\text { Product } \\
\text { Information } \\
\text { (IPI) }\end{array}$} & IPI_1 & $\begin{array}{l}\text { To me product information is of major importance. I need to } \\
\text { know what the product contains. }\end{array}$ \\
\hline & IPI_2 & I compare labels to select the most nutritious food. \\
\hline & IPI_3 & $\begin{array}{l}\text { I compare product information labels to decide which brand to } \\
\text { try. }\end{array}$ \\
\hline \multirow{3}{*}{$\begin{array}{l}\text { Price Criteria } \\
\quad(\text { PRC) }\end{array}$} & PRC_1 & I always check prices, even on small items. \\
\hline & PRC_2 & I notice when products I buy regularly change in price. \\
\hline & PRC_3 & $\begin{array}{l}\text { I watch for ads in the newspaper for shop specials and plan to } \\
\text { take advantage of them when I go shopping. }\end{array}$ \\
\hline \multirow{3}{*}{$\begin{array}{l}\text { Health } \\
\text { (HLT) }\end{array}$} & HLT_1 & I prefer to buy natural products, ie products without preservatives. \\
\hline & HLT_2 & $\begin{array}{l}\text { To me the naturalness of the food that I buy is an important } \\
\text { quality. }\end{array}$ \\
\hline & HLT_3 & I try to avoid food products with additives. \\
\hline \multirow{3}{*}{$\begin{array}{l}\text { Convenience } \\
\quad(\mathbf{C N V})\end{array}$} & CNV_1 & I use a lot of frozen foods in my cooking. \\
\hline & CNV_2 & We use a lot of ready-to-eat foods in our household. \\
\hline & CNV_3 & I use a lot of mixes, for instance baking mixes and powder soups. \\
\hline \multirow{10}{*}{$\begin{array}{l}\text { Atittude } \\
\text { (ATT) }\end{array}$} & ATT_1 & $\begin{array}{c}\text { Organic food is produced in a way that is better for the } \\
\text { environment. }\end{array}$ \\
\hline & ATT_2 & Organic food is natural. \\
\hline & ATT_3 & Organic food is free from pesticides. \\
\hline & ATT_4 & Organic food is healthier. \\
\hline & ATT 5* & Products sold as organic are not really organic. \\
\hline & ATT 6* & Organic is merely a marketing gimmick. \\
\hline & ATT_7 & Organic food tastes better. \\
\hline & ATT 8* & Organic food expires faster. \\
\hline & ATT 9* & Processed foods can be organic. \\
\hline & ATT $10^{*}$ & Organic food can be cheap \\
\hline \multirow{3}{*}{$\begin{array}{l}\text { Purchase } \\
\text { Intention } \\
\text { (PCI) }\end{array}$} & PCI_1 & I am willing to buy this organic food in the future. \\
\hline & PCI_2 & I plan to purchase this organic food. \\
\hline & PCI_3 & I will make effort to buy this organic food. \\
\hline
\end{tabular}

*Excluded variables

Source: Results of research. 


\section{Appendix 2}

\section{Demographic Data}

\section{Sample characteristics}

Gender

Female

Male

Age

Between 18 and 24 years

Between 25 and 34 years

Between 35 and 44 years

Between 45 and 54 years

Between 55 and 64 years

More than 65 years

Education of respondent

Elementary School

High School

University

High degree level (31aster or doctorate degree)
479

172

$26.42 \%$

92

141

153

138

91

36

$14.13 \%$

$21.66 \%$

$23.50 \%$

$21.20 \%$

$13.98 \%$

$5.53 \%$

$1.69 \%$

11

$8.45 \%$

55

317

$48.69 \%$

268

$41.17 \%$

Occupation

Student

111

$17.05 \%$

Household

60

$9.22 \%$

Retiree

$9.06 \%$

Employed

244

$37.48 \%$

Entrepreneur

169

$25.96 \%$

Unemployed

Total of respondents

Source: Results of research.

651

$100 \%$




\section{Appendix 3}

Discriminant Validity - Chin (1998) Criterion: Crossloadings Matrix ( $n=651)$

\begin{tabular}{|c|c|c|c|c|c|c|}
\hline Items & $\begin{array}{l}\text { Importance of } \\
\text { product } \\
\text { information } \\
\text { (IPI) }\end{array}$ & $\begin{array}{l}\text { Price criteria } \\
\quad \text { (PRC) }\end{array}$ & Health (HLT) & $\begin{array}{l}\text { Convenience } \\
\text { (CNV) }\end{array}$ & $\begin{array}{l}\text { Attitude } \\
\text { (ATT) }\end{array}$ & $\begin{array}{l}\text { Purchase } \\
\text { Intention } \\
\text { (PCI) }\end{array}$ \\
\hline IPI_1 & .781 & .257 & .509 & .179 & .303 & .378 \\
\hline IPI_2 & .837 & .294 & .508 & .206 & .251 & .403 \\
\hline IPI_3 & .873 & .312 & .466 & .211 & .236 & .387 \\
\hline PRC_1 & .282 & .793 & .158 & .060 & .134 & .140 \\
\hline PRC _2 & .293 & .809 & .270 & .148 & .223 & .206 \\
\hline PRC _3 & .255 & .798 & .190 & .050 & .126 & .154 \\
\hline HLT_1 & .452 & .235 & .826 & .257 & .422 & .472 \\
\hline HLT_2 & .522 & .206 & .825 & .236 & .469 & .611 \\
\hline HLT_3 & .469 & .195 & .777 & .185 & .297 & .406 \\
\hline CNV_1 & .175 & .081 & .212 & .811 & .063 & .072 \\
\hline CNV_2 & .160 & .120 & .208 & .784 & .100 & .085 \\
\hline CNV_3 & .224 & .063 & .236 & .751 & .081 & .118 \\
\hline ATT_1 & .192 & .165 & .333 & .078 & .737 & .433 \\
\hline ATT_2 & .200 & .167 & .390 & .070 & .689 & .378 \\
\hline ATT_3 & .255 & .092 & .315 & .005 & 697 & .423 \\
\hline ATT_4 & .196 & .170 & .387 & .051 & .799 & .477 \\
\hline ATT_7 & .302 & .160 & .382 & .154 & .755 & .594 \\
\hline PCI_1 & .347 & .169 & .491 & .086 & .566 & .850 \\
\hline PCI_2 & .456 & .186 & .626 & .123 & .559 & .889 \\
\hline PCI_3 & .419 & .196 & .491 & .097 & .545 & .877 \\
\hline
\end{tabular}

Source: Research results. 


\section{Appendix 4}

\section{Table 5 - Measurement Scales}

\begin{tabular}{|c|c|c|}
\hline Construct & Label & Item \\
\hline \multirow{3}{*}{$\begin{array}{l}\text { Importance of } \\
\text { Product } \\
\text { Information } \\
\text { (IPI) }\end{array}$} & IPI_1 & $\begin{array}{l}\text { To me product information is of major importance. I need to know } \\
\text { what the product contains. }\end{array}$ \\
\hline & IPI_2 & I compare labels to select the most nutritious food. \\
\hline & IPI_3 & I compare product information labels to decide which brand to try. \\
\hline \multirow{3}{*}{$\begin{array}{l}\text { Price Criteria } \\
\text { (PRC) }\end{array}$} & PRC_1 & I always check prices, even on small items. \\
\hline & PRC_2 & I notice when products I buy regularly change in price. \\
\hline & PRC_3 & $\begin{array}{l}\text { I watch for ads in the newspaper for shop specials and plan to take } \\
\text { advantage of them when I go shopping. }\end{array}$ \\
\hline \multirow{3}{*}{$\begin{array}{l}\text { Health } \\
\text { (HLT) }\end{array}$} & HLT_1 & I prefer to buy natural products, ie products without preservatives. \\
\hline & HLT_2 & To me the naturalness of the food that I buy is an important quality. \\
\hline & HLT_3 & I try to avoid food products with additives. \\
\hline \multirow{3}{*}{$\begin{array}{l}\text { Convenience } \\
\text { (CNV) }\end{array}$} & CNV_1 & I use a lot of frozen foods in my cooking. \\
\hline & CNV_2 & We use a lot of ready-to-eat foods in our household. \\
\hline & CNV_3 & I use a lot of mixes, for instance baking mixes and powder soups. \\
\hline \multirow{10}{*}{$\begin{array}{l}\text { Atittude } \\
\text { (ATT) }\end{array}$} & $\mathrm{ATT}_{-1}$ & Organic food is produced in a way that is better for the environment. \\
\hline & ATT_2 & Organic food is natural. \\
\hline & ATT_3 & Organic food is free from pesticides. \\
\hline & ATT_4 & Organic food is healthier. \\
\hline & ATT 5* & Products sold as organic are not really organic. \\
\hline & ATT 6* & Organic is merely a marketing gimmick. \\
\hline & ATT_7 & Organic food tastes better. \\
\hline & ATT $8 *$ & Organic food expires faster. \\
\hline & $\begin{array}{l}\text { ATT } 9 \\
*\end{array}$ & Processed foods can be organic. \\
\hline & $\begin{array}{l}\text { ATT } \\
10^{*} \\
\end{array}$ & Organic food can be cheap \\
\hline \multirow{3}{*}{$\begin{array}{l}\text { Purchase } \\
\text { Intention } \\
\text { (PCI) }\end{array}$} & PCI_1 & I am willing to buy this organic food in the future. \\
\hline & PCI_2 & I plan to purchase this organic food. \\
\hline & PCI_3 & I will make effort to buy this organic food. \\
\hline
\end{tabular}

*Excluded variables.

Source: Research results 


\title{
EFEITO DO ESTILO DE VIDA RELACIONADO À ALIMENTAÇÃO ORGÂNICA NA ATITUDE E INTENÇÃO DE COMPRA DE ALIMENTOS ORGÂNICOS: EVIDÊNCIAS DO BRASIL
}

\author{
Bruna Ferreira Jungles \\ Mestre em Administração pela Faculdade de Ciências Agrárias e Veterinárias - Universidade Estadual Paulista / FCAV- UNESP \\ Pesquisadora do Grupo Ânima (CNPq) e Gerente de Operações - Lojas Renner \\ Araraquara, SP, Brasil \\ brunajungles@hotmail.com \\ Sheila Farias Alves Garcia \\ Doutora em Administração pela Universidade de São Paulo, Faculdade de Economia Administração e Contabilidade de São Paulo - \\ USP/FEA \\ Professora no Programa de Pós-Graduação em Administração da Universidade Estadual Paulista, Faculdade de Ciências Agrárias e \\ Veterinárias - UNESP/FCAV \\ Coordenadora do Grupo Ânima - Pesquisa e Extensão (CNPq) \\ Jaboticabal, SP, Brasil \\ sheila.garcia@unesp.br \\ Dirceu Tornavoi de Carvalho \\ Professor Associado \\ Universidade de São Paulo, Faculdade de Economia Administração e Contabilidade de Ribeirão Preto - FEA/RP-USP \\ Ribeirão Preto, SP. Brasil \\ tornavoi@usp.br \\ Sérgio Silva Braga Junior \\ Doutor em Administração pela Universidade Nove de Julho (UNINOVE) \\ Livre-Docente pela Universidade Estadual Paulista - UNESP. \\ Professor no Programa de Pós-Graduação em Agronegócio e Desenvolvimento e do Programa de Pós-Graduação em Administração da \\ Universidade Estadual Paulista (UNESP/FCE e UNESP/FCAV). \\ Tupã, SP - Brasil. \\ sergio.braga@unesp.br \\ Dirceu da Silva \\ Doutor em Educação pela Universidade de São Paulo - USP \\ Professor na Universidade de Campinas - UNICAMP \\ Campinas/SP - Brasil \\ dirceu@unicamp.br
}

Objetivo: Analisar, no contexto brasileiro, o efeito do estilo de vida relacionado à alimentação orgânica na atitude e intenção de compra dos alimentos orgânicos.

Método: Foi desenvolvida uma estrutura conceitual, com um constructo de segunda ordem, o estilo de vida relacionado à alimentação orgânica (OFRL), para avaliar seu impacto na atitude e na intenção de compra, por meio de um survey online com 651 consumidores brasileiros (amostra não-probabilística). Para a análise dos dados, o método escolhido foi a Modelagem de Equações Estruturais, por mínimos quadrados parciais e modelos de caminhos (PLS-PM), utilizandose o software SmartPLS 2.0.

Originalidade / Relevância: Este estudo amplia a literatura e fornece novos insights ao analisar as consequências do OFRL sobre a atitude e intenção de compra de alimentos orgânicos.

Resultados: O constructo OFRL é um bom preditor para a intenção de compra de alimentos orgânicos e apresenta forte relação com a atitude, que desempenha um papel mediador na relação OFRL-intenção de compra, melhorando o papel preditivo do estilo de vida relacionado aos alimentos orgânicos em relação à intenção de compra. O modelo explica $19 \%$ da variância de atitude e $51 \%$ da variância de intenção de compra.

Contribuições teórico-metodológicas: Do ponto de vista teórico, este trabalho inova ao propor um constructo de segunda ordem único, composto por variáveis latentes ligadas ao estilo de vida relacionado à alimentação orgânica (OFRL), para medir seu impacto na formação de atitude e intenção de compra em relação aos alimentos orgânicos.

Palavras-chave: Comportamento do consumidor; Atitude; Teoria do comportamento planejado; Estilo de vida relacionado à alimentação; Modelagem de equações estruturais.

\section{Como citar}

American Psychological Association (APA)

Jungles, B. F., Garcia, S. F. A., Carvalho, D. T., Jr. Braga, S. S., \& Silva, D. (2021, out./dez.). Efeito do estilo de vida relacionado à alimentação orgânica na atitude e intenção de compra de alimentos orgânicos: evidências do Brasil. Revista Brasileira de Marketing - ReMarK, 20(4), 286 - 320.

https://doi.org/10.5585/remark.v20i4.19192. 


\section{Introdução}

Há uma tendência global crescente consistente em relação aos alimentos orgânicos, que estimula produtores e comerciantes desses alimentos a conhecer os determinantes de seu consumo (Janssen, 2018; Katt \& Meixner, 2020). Pesquisas empíricas anteriores sobre alimentos orgânicos analisaram amplamente o processo de decisão de compra, buscando acessar os principais atributos avaliados pelos consumidores, bem como os benefícios e barreiras ao consumo desses alimentos (Aschemann-Witzel \& Aagaard, 2014; Britwum, Bernard \& Albrecht, 2020; Carfora, Cavallo, Caso, Del Giudice, De Devitiis, Viscecchia \& Cicia, 2019; Ergönül \& Ergönül, 2015; Katt e Meixner, 2020; Rana e Paul, 2017; Wekeza e Sibanda, 2019).

No caso dos alimentos orgânicos, os atributos mais valorizados, não são observáveis antes da compra ou durante o consumo. Na verdade, eles estão relacionados ao processo de produção e seu impacto no meio ambiente e na saúde humana. Eles têm que ser credenciados, que é uma das razões pelas quais esses alimentos costumam ser certificados. Mesmo quando esses atributos são certificados, os consumidores precisam ter certeza de que estão realmente recebendo tais atributos em suas compras. "A análise dos determinantes do consumo de alimentos orgânicos não é simples, nem direta. [...] a disposição para pagar (WTP) por alimentos orgânicos é mais complexa do que normalmente se percebe [...] (Britwum et al., 2021, p.1).

Mais do que atributos, o consumo de alimentos orgânicos é definido pelos valores e atitudes de seus consumidores. Uma revisão sistemática da produção científica recente (19992019) revelou que a preocupação com o meio ambiente e a saúde, aspectos ligados aos valores e atitudes do consumidor, importam mais do que os aspectos relacionados ao produto. $\mathrm{Na}$ maioria dos estudos analisados, essas variáveis apresentaram influência positiva e significante na WTP por alimentos orgânicos (Katt \& Meixner, 2020).

A revisão da literatura aponta possíveis relações entre o consumo de alimentos orgânicos e estilos de vida saudáveis. A crescente incidência de doenças causadas pelas escolhas alimentares tem levado os consumidores a rever seus hábitos, em busca de uma melhor qualidade de vida (Rana \& Paul, 2017). Nesse movimento, o consumo de alimentos orgânicos parece estar vinculado a padrões de comportamento mais saudáveis e sustentáveis, dando origem a um novo estilo de vida pró-orgânico (Oroian, Safirescu, Harun, Chiciudean, Arion, Muresan \& Bordeanu 2017). 
$\mathrm{Na}$ literatura, há estudos que buscam segmentar os consumidores a partir de suas percepções e atitudes em relação aos alimentos orgânicos. Uma dessas publicações identificou três segmentos: 1) Preocupados com o meio ambiente (52,8\%): foco em sustentabilidade e saúde; 2) Preocupados com a saúde (35\%): foco na saúde e preocupação com o peso e 3) Gourmand $(12,2 \%)$ : foco na saúde e nos aspectos sensoriais. Tais resultados indicam que o componente de consumo natural e sustentável da análise fatorial (do método usado pelo autor) tem grande importância no processo de decisão de compra de alimentos orgânicos. Significa que, para o consumidor orgânico, além de saciar a fome, o alimento deve conter características adicionais, ligadas ao desenvolvimento e consumo sustentáveis, mas também aspectos éticos como bem-estar animal, segurança ambiental e ausência de agrotóxicos (Oroian et al. 2017). Os resultados da pesquisa não podem ser generalizados (referem-se aos consumidores da região Noroeste da Romênia), mas o trabalho levanta um aspecto importante: o estilo de vida dos consumidores orgânicos.

O crescimento do mercado orgânico é atribuído à mudança no estilo de vida do consumidor (Oroian et al., 2017; Rana \& Paul, 2017). A constatação de que o estilo de vida está entre os principais determinantes do consumo de alimentos orgânicos tem chamado a atenção de pesquisadores para entender a relação entre esse constructo e o comportamento pró-orgânico. A literatura fornece evidências de que existe uma ligação entre alimentos orgânicos e um estilo de vida ativo (Goetzke \& Sipiller, 2014).

De acordo com Anderson e Golden (1984), a abordagem de estilo de vida foi integrada na literatura de comportamento do consumidor na década de 1950 por Bell (1958), Havighurst e Feigenbaum (1959), bem como por Rainwater et al. (1959). A pesquisa de estilo de vida em marketing é usada principalmente para segmentação de mercado (Plummer, 1974). De forma prática, o estilo de vida combina as virtudes da demografia com a riqueza e dimensionalidade das características psicológicas (Thøgersen, 2017). O conceito é definido na literatura de marketing como padrões de vida, expressos por atividades, interesses e opiniões, que geram uma caracterização capaz de representar um indivíduo de forma abrangente, bem como sua interação com o meio em que vive. O estilo de vida é concebido como uma construção mental, que não é o comportamento em si, mas explica o comportamento (Grunert, Brunsø \& Bisp, 1993).

Na pesquisa sobre estilo de vida, está cada vez mais claro que as pessoas podem ter não apenas um, mas muitos estilos de vida interconectados. Em outras palavras, o estilo de vida depende do domínio ou contexto analisado. (Grunert, Brunsø \& Bisp, 1995). Em situações 
específicas, o estilo de vida é considerado o pano de fundo que enquadra as percepções de um consumidor de produtos e serviços e orienta suas escolhas e comportamentos (Thøgersen, 2017).

Na indústria de alimentos, Grunert, Brunsø \& Bisp (1993, 1995) propuseram um modelo de Estilo de Vida Relacionado a Alimentos (FRL) caracterizado por eles como uma abordagem dedutiva e cognitiva para a pesquisa de estilo de vida. Inspirando-se na Teoria da Cadeia de Meios-Fim (Gutman, 1982), eles definem o estilo de vida relacionado ao domínio de alimentos como "o sistema de categorias cognitivas, scripts e suas associações, que relacionam um conjunto de produtos a um conjunto de valores" (Grunert, Brunsø \& Bisp, 1993, p. 13).

Apesar do crescente interesse pelo estudo do comportamento do consumidor orgânico e da importância do estilo de vida neste contexto, ainda existem lacunas a serem exploradas. Entre eles, a relação entre estilo de vida relacionado à alimentação e consumo orgânico. Até a elaboração da presente pesquisa, não foram encontradas evidências empíricas do impacto do estilo de vida relacionado à alimentação na intenção de compra de alimentos orgânicos.

O objetivo desta pesquisa é analisar o efeito do estilo de vida relacionado à alimentação sobre a atitude e intenção de compra de alimentos orgânicos, com base na clássica relação hierárquica da Teoria do Comportamento Planejado - TPB (crenças-atitudes-intenção de compra). Estudos que visem identificar os fatores do estilo de vida relacionado à alimentação que se correlacionam com a atitude e intenção de compra de alimentos orgânicos trazem relevantes contribuições teóricas. Isso permitirá prever tendências e orientar os sistemas de produção, distribuição e promoção com mais precisão (Vera, Pérez, Puig \& Montero-Vicente, 2016).

Sob o prisma econômico, o mercado brasileiro, apesar do movimento tímido quando comparado aos países que consomem mais produtos orgânicos, vem apresentando aumento tanto no valor das vendas, quanto na produção e no número de produtores. Em 2020, o mercado brasileiro de orgânicos atingiu cerca de $\mathrm{R} \$ 5,8$ bilhões, um crescimento de $30 \%$ em relação a 2019, segundo a Associação Organis (ABRAS, 2021). Além disso, esta pesquisa também contribui com implicações gerenciais, recomendações e oportunidades para a indústria de alimentos orgânicos.

\section{Revisão da literatura}

Muitos estudos empíricos foram realizados a fim de compreender por que os consumidores compram, ou não compram, alimentos orgânicos e assim identificar os 
impulsionadores do consumo de alimentos orgânicos. Grande parte desses estudos realizados com consumidores de alimentos orgânicos busca entender o processo de decisão de compra e avaliar quais são os atributos valorizados, os benefícios desejados e as barreiras ao consumo dessa categoria de alimentos (Britwum et al., 2020; Carfora et al. 2019; Janssen, 2018; Katt e Meixner, 2020; Rana \& Paul, 2017; Wekeza e Sibanda, 2019).

Em 2020, uma revisão sistemática da literatura abrangendo duas décadas de publicação científica (1999-2019), identificou os principais determinantes da WTP por alimentos orgânicos (Katt \& Meixner, 2020). Os resultados foram agrupados em três categorias de análise: fatores relacionados ao consumidor, fatores relacionados ao produto e fatores relacionados ao local de compra. Na categoria de fatores relacionados ao consumidor, além dos fatores demográficos, valores e atitudes desempenham um papel importante, com destaque para duas variáveis: 1) preocupação com o meio ambiente que apresentou, na maioria dos estudos, forte impacto na disposição de consumo de produtos orgânicos; 2) preocupação com a saúde, teve um efeito positivo na WTP orgânica (Katt \& Meixner, 2020).

Ainda na mesma pesquisa (Katt \& Meixner, 2020), na categoria fatores relacionados aos atributos do produto, o preço é a variável mais recorrente. No entanto, não há consenso quanto ao impacto dessa variável na WTP por alimentos orgânicos. Por outro lado, alguns estudos revelaram um impacto positivo do preço na disposição de comprar produtos orgânicos (Hasselbach \& Roosen, Probst et al. 2012; 2015; Zielke, 2010). A falta de consenso torna adequado o uso dessa variável para compor o conjunto de determinantes do consumo orgânico. Além do preço, a familiaridade e o envolvimento com o produto, bem como a sua disponibilidade, também afetam a WTP. A pesquisa não fala diretamente sobre estilo de vida alimentar (Katt \& Meixner, 2020).

Apesar do crescente interesse pelo comportamento do consumidor orgânico, existem lacunas a serem exploradas na relação entre estilo de vida e consumo orgânico. Goetzke e Sipiller (2014) investigam se os consumidores de alimentos funcionais e orgânicos têm a mesma compreensão de saúde e quais estilos de vida adotam para melhorar a saúde e o bemestar. De forma a medir as diferenças perceptuais em relação ao bem-estar e aos estilos de vida saudáveis, a escala Atividades, Interesses e Opiniões (AIO) foi adaptada às dimensões e conceitos teóricos de bem-estar.

Os consumidores de alimentos funcionais têm um conceito de saúde e bem-estar semelhante ao dos consumidores orgânicos, mas diferem em certos aspectos na maneira de alcançá-lo. A compra de alimentos orgânicos e funcionais é impulsionada por diferentes estilos 
de vida. Em geral, os resultados confirmam a ligação entre alimentação orgânica e estilo de vida ativo, enquanto a alimentação funcional está ligada a um estilo de vida passivo (Goetzke e Sipiller 2014).

Observa-se que, para os consumidores, o consumo de alimentos orgânicos faz parte de um modo de vida, que resulta de uma ideologia ligada a um sistema de valores particulares, que afeta as atitudes e o comportamento do consumidor (Hughner et al., 2007). Como os estilos de vida são multidimensionais, eles dependem de múltiplos fatores de interação e podem evoluir ao longo do tempo e com as circunstâncias do indivíduo (Aschemann-Witzel et al., 2018).

A revisão da literatura na fase exploratória desta pesquisa, deu origem a um estudo bibliométrico, que levou à seleção variáveis do estilo de vida relacionado à alimentação que estariam mais relacionados ao consumo orgânico. Essas variáveis serão utilizadas para compor um constructo de segunda ordem, aqui denominado estilo de vida relacionado à alimentação orgânica (OFRL). A presente seção resume o estado da arte dessas variáveis de estilo de vida relacionado aos alimentos orgânicos e apresenta as hipóteses do estudo.

Os resultados do estudo bibliométrico levaram à seleção de quatro dimensões do estilo de vida relacionado aos alimentos - (FRL) (Grunert, Brunsø \& Bisp, 1993; 1995), que, hipoteticamente, estariam mais relacionadas ao consumo orgânico: importância da informação do produto, critérios de preço, saúde e conveniência. Neste artigo, como foi relatado, essas dimensões serão utilizadas como variáveis operacionais, para compor um constructo de segunda ordem, aqui denominado estilo de vida relacionado à alimentação orgânica (OFRL), cujo impacto na atitude e intenção de compra dos alimentos orgânicos será analisado. A seção que segue explica o estilo de vida relacionado à alimentação orgânica, as variáveis operacionais e apresenta as hipóteses do estudo.

\subsection{Estilo de vida relacionado a alimentos orgânicos}

O estilo de vida relacionado à alimentação orgânica é um constructo de segunda ordem composto por quatro variáveis latentes, extraídas do FRL (Grunert, Brunsø \& Bisp, 1993; 1995), que funcionam como variáveis operacionais do construto de segunda ordem. A escala FRL foi desenvolvida com o objetivo de segmentar os consumidores de acordo com seus hábitos alimentares, atitudes e valores associados (Grunert, 1993).

O estilo de vida define o padrão de consumo que reflete as escolhas de um indivíduo sobre como gastar seu tempo e dinheiro, escolhas que desempenham um papel fundamental na definição da identidade do consumidor e sua interação com o meio em que vive. No caso dos 
alimentos, os constructos pretendem medir as atitudes dos consumidores em relação aos alimentos, compras e processos de consumo em diferentes contextos, buscando caracterizar as pessoas pelas funções que os alimentos desempenham em suas vidas e realizar as consequências desejadas (Thøgersen, 2017; Goetzke \& Sipiller, 2014; Pérez -Cueto, et al., 2010).

A escala FRL foi composta originalmente por 23 dimensões, distribuídas nos cinco domínios do estilo de vida alimentar (formas de fazer compras, aspectos de qualidade, métodos de preparação dos alimentos, situações de consumo e motivos de compra), totalizando 69 variáveis operacionais. O objetivo do instrumento é segmentar os consumidores de acordo com seu estilo de vida alimentar, portanto nem todas as variáveis estão diretamente relacionadas aos alimentos orgânicos.

Como a aplicação da escala completa não seria necessária, nem adequada, para os fins da presente pesquisa, foram identificadas as dimensões e domínios relacionados ao consumo orgânico. Assim, para desenvolver o modelo de pesquisa deste artigo, os critérios escolhidos dos quatro fatores para compor o OFRL foram baseados em: 1) revisão da literatura, que postula a importância desses fatores para o comportamento de consumo pró-orgânico e 2) avaliação técnica de três especialistas (doutores na área). A relação entre cada uma das quatro variáveis operacionais com alimentos orgânicos será explicada na próxima seção.

\section{1.1 Importância das informações do produto}

A literatura indica que o termo "orgânico" é interpretado de maneiras diferentes, uma vez que muitos consumidores ainda não estão familiarizados com os padrões e práticas de produção orgânica (Chryssochoidis, 2000; Harper \& Makatouni, 2002; Vukasovic, 2013). Além disso, há uma grande variedade de contextos, onde os consumidores não apresentam as mesmas características geográficas, demográficas, psicográficas e comportamentais, além de que as interpretações do termo pelos produtores e reguladores podem diferir das dos consumidores (Aertsens et al., 2009; Zanoli \& Naspetti, 2002).

Tais diferenças interpretativas e equívocos acabam acentuando a variedade de significados, crenças e confusões sobre o conceito (Chryssochoidis, 2000; Harper \& Makatouni, 2002; Vukasovic, 2013). Uma das alternativas para solucionar as lacunas geradas pelas múltiplas crenças e confusões relacionadas ao termo orgânico é estimular o acesso à informação, função de extrema importância para estimular a demanda, uma vez que, os consumidores buscam um volume cada vez maior de informações sobre os produtos, para 
subsidiar suas decisões de compra (Lim, Yong \& Suryadi, 2014; Sangkumchaliang \& Huang, 2012).

Nesse sentido, a rotulagem de alimentos é uma estratégia importante para auxiliar os consumidores no processo de escolha de alimentos e pode ser uma aliada para o desenvolvimento do mercado de orgânicos (Prada, Garrido, \& Rodrigues, 2017). Além disso, a rotulagem é uma forma de comunicar intensamente o alto valor e os atributos éticos dos alimentos orgânicos aos consumidores, uma vez que, para a maioria dos consumidores, a relação preço-desempenho, e não apenas o preço, parece ser decisiva (Piqueras-Fiszman \& Spence, 2015; Rödiger, Plaßmann, \& Hamm, 2016).

A presença de rótulos nos alimentos embalados, que trazem informações nutricionais e de saúde, influencia fortemente a atitude e as intenções de compra dos consumidores (Rana \& Paul, 2017), pois os consumidores estão cada vez mais interessados em informações confiáveis e na facilidade de comparação entre produtos orgânicos e não orgânicos (Gottschalk \& Leistner, 2012).

\subsubsection{Critérios de preço}

O preço premium dos alimentos orgânicos sobre os convencionais tem sido de grande interesse para os pesquisadores, uma vez que o critério preço desempenha um papel significativo no processo de tomada de decisão e expressa uma das barreiras mais relevantes para o consumo de alimentos orgânicos (Aertsens et al., 2009; Shin, 2018; Gottschalk \& Leistner, 2012; Hughner et al., 2007; Rödiger , Plaßmann, \& Hamm, 2016; Rödiger \& Hamm, 2015).

O conceito de disponibilidade para pagar (DPP), em inglês, willingness to pay (WTP), refere-se à quantidade máxima de dinheiro que um indivíduo está disposto a pagar por um produto, serviço, atributo ou benefício (Homburg, Koschate \& Hoyer, 2005). No contexto dos alimentos orgânicos, a WTP foi explorada por vários estudos (Achilleas \& Anastasios, 2008; Essoussi \& Zahaf, 2008; Gerrard et al., 2013; Gonzalez, 2012; Mondelaers, Verbeke \& Huylenbroeck, 2009), já que o preço dos alimentos orgânicos é, frequentemente, mais elevado do que os convencionais, devido à falta de economias de escala e aos custos adicionais no processo de produção (Aertsens et al., 2009; Konuk, 2017).

Entretanto, a concepção do preço como barreira à compra dos alimentos orgânicos, resultado relatado com frequência em pesquisas na área, nem sempre se constitui na melhor explicação. Se por um lado tem sido relatado que o preço é uma barreira importante à compra, 
por outro o volume do mercado está crescendo e as tendências do comportamento do consumidor em relação à qualidade-preço indicam oportunidades razoáveis para os mercados orgânicos (Rödiger \& Hamm, 2015). Alguns estudos revelaram um impacto positivo do preço na disposição de comprar produtos orgânicos (Hasselbach \& Roosen, 2015; Probst et al. 2012; Zielke, 2010). A falta de consenso torna adequado o uso dessa variável para compor o conjunto de determinantes do consumo orgânico (Katt \& Meixner, 2020).

\subsubsection{Saúde}

Há consenso de que a demanda por alimentos orgânicos aumentou, substancialmente, nas duas últimas décadas, devido às mudanças na percepção do consumidor sobre os alimentos, que não são mais apenas um meio de saciar a fome, mas ganharam múltiplas dimensões devido às preocupações dos consumidores com questões relacionadas à sua saúde (Oroian, et al., 2017). Ao tomar decisões relacionadas à escolha alimentar, o consumidor considera os potenciais benefícios à saúde que o produto pode proporcionar, devido à crescente importância desse fator (Yazdanpanah, Forouzani \& Hojjati, 2015).

Observa-se que consumidores preocupados com a saúde demonstram preferência por alimentos orgânicos (Ergönül \& Ergönül, 2015; Hemmerling, Hamm \& Spiller, 2015). Esse crescente interesse por questões relacionadas à saúde estimula o consumo, pois a escolha de alimentos orgânicos versus convencionais é influenciada pela percepção dos benefícios à saúde proporcionados pelos primeiros (Paul \& Rana, 2012; Yazdanpanah, Forouzani, \& Hojjati, 2015).

Outro destaque é a crescente preocupação das famílias com a saúde e nutrição de seus filhos, fator que incentiva o consumo de alimentos com maiores valores nutricionais, com menos aditivos e provenientes de métodos naturais de produção (Aertsens et al. , 2009; Hughner et al., 2007).

Assim, as preocupações do consumidor relacionadas à saúde e a percepção positiva dos consumidores em relação aos benefícios causados pelo consumo de alimentos orgânicos seriam um fator importante que afetaria o comportamento de compra de alimentos orgânicos e seriam capazes de predizer a intenção de compra (Ergönül \& Ergönül , 2015; Yazdanpanah, Forouzani, \& Hojjati, 2015) 


\subsubsection{Conveniência}

Enquanto os consumidores buscam alternativas mais saudáveis também querem facilitar os processos de compra, preparo e consumo, buscando produtos que maximizem sua produtividade em termos de consumo de tempo em todas as etapas do processo de escolha dos alimentos (Reid, Li, Bruwer \& Grunert, 2001).

Mudanças nos padrões de estilo de vida têm mostrado que os consumidores passaram a reduzir seu tempo para planejar e preparar refeições, aumentando a demanda por conveniência nos alimentos (Oroian, et al., 2017; Rana \& Paul, 2017). Alimentos convenientes são definidos como itens parcialmente ou totalmente preparados em que o tempo de preparação, habilidades culinárias ou esforços físicos foram significativamente transferidos do consumidor para o processador ou distribuidor de alimentos (Capps, Tedford, \& Havlicek, 1985)

Com o crescimento do mercado a necessidade de disponibilizar produtos orgânicos no mercado é considerável, uma vez que a disponibilidade leva à venda e atrai novos clientes (Gottschalk \& Leistner, 2012). Porém, cada vez mais a busca por conveniência exige mais do que alimentos orgânicos frescos, visto que o consumidor busca saúde e praticidade. Portanto, é importante oferecer alimentos orgânicos, com uma mistura desses três elementos.

\subsection{Atitude}

A maioria das definições contemporâneas de atitude refere-se à organização cognitiva e afetiva, tanto em relação a um objeto quanto à predisposição para agir (McBroom \& Reed, 1992). Na pesquisa sobre comportamento do consumidor foram desenvolvidos estudos sobre a sequência hierárquica causal crença-atitude-intenção que embasou o desenvolvimento de diversas teorias, entre as quais se destaca, por sua flexibilidade e poder de explicação, a Teoria da Ação Racional (Ajzen \& Fishbein, 1973) e sua sucessora, a Teoria do Comportamento Planejado (TPB) (Ajzen, 1991). A TPB assume que a intenção comportamental é determinada pela atitude, norma subjetiva e pela percepção de controle comportamental (Ajzen, 1991).

No caso do consumo de alimentos orgânicos, a TPB parece ser consistente, relatando uma relação positiva significante entre a atitude em relação aos alimentos orgânicos e a intenção de compra desses alimentos (Al-Swidi et al., 2014; Carfora et al., 2019; Kuran \& Mihic, 2014; Meyer-Hofer et al., 2015; Tarkiainen \& Sundqvist, 2005; Thøgersen, 2017; Yadav \& Pathak, 2016; Watanabe, Alfinito \& Hamza, 2020).

A atitude é um dos mais importantes preditores da intenção de comprar alimentos orgânicos (Carfora et al., 2019; Chen \& Lobo, 2012; Watanabe, Alfinito \& Hamza, 2020; Wirth, 
Stanton \& Wiley, 2011) e alguns estudos confirmaram que, em geral, os consumidores têm uma atitude positiva em relação a esses alimentos (Aertsens et al., 2009; Harper \& Makatouni, 2002; Vukasovic, 2013) devido a duas questões que afetam seu comportamento de compra: 1) maior atenção à qualidade e à segurança alimentar, evidenciando um aumento na demanda por alimentos saudáveis, nutritivos e seguros; 2) o desenvolvimento da responsabilidade social (Savelli et al., 2017).

\subsection{Modelo de Pesquisa e Hipóteses}

O arcabouço conceitual, apresentado na Figura 1, é o modelo de pesquisa que estabelece a relação entre OFRL e a intenção de compra como seu objeto central. Os determinantes do estilo de vida relacionados aos alimentos orgânicos são formados por variáveis latentes que funcionam como variáveis operacionais (importância das informações sobre o produto, critérios de preço, saúde e conveniência).

\section{Figura 1}

\section{Modelo da Pesquisa}

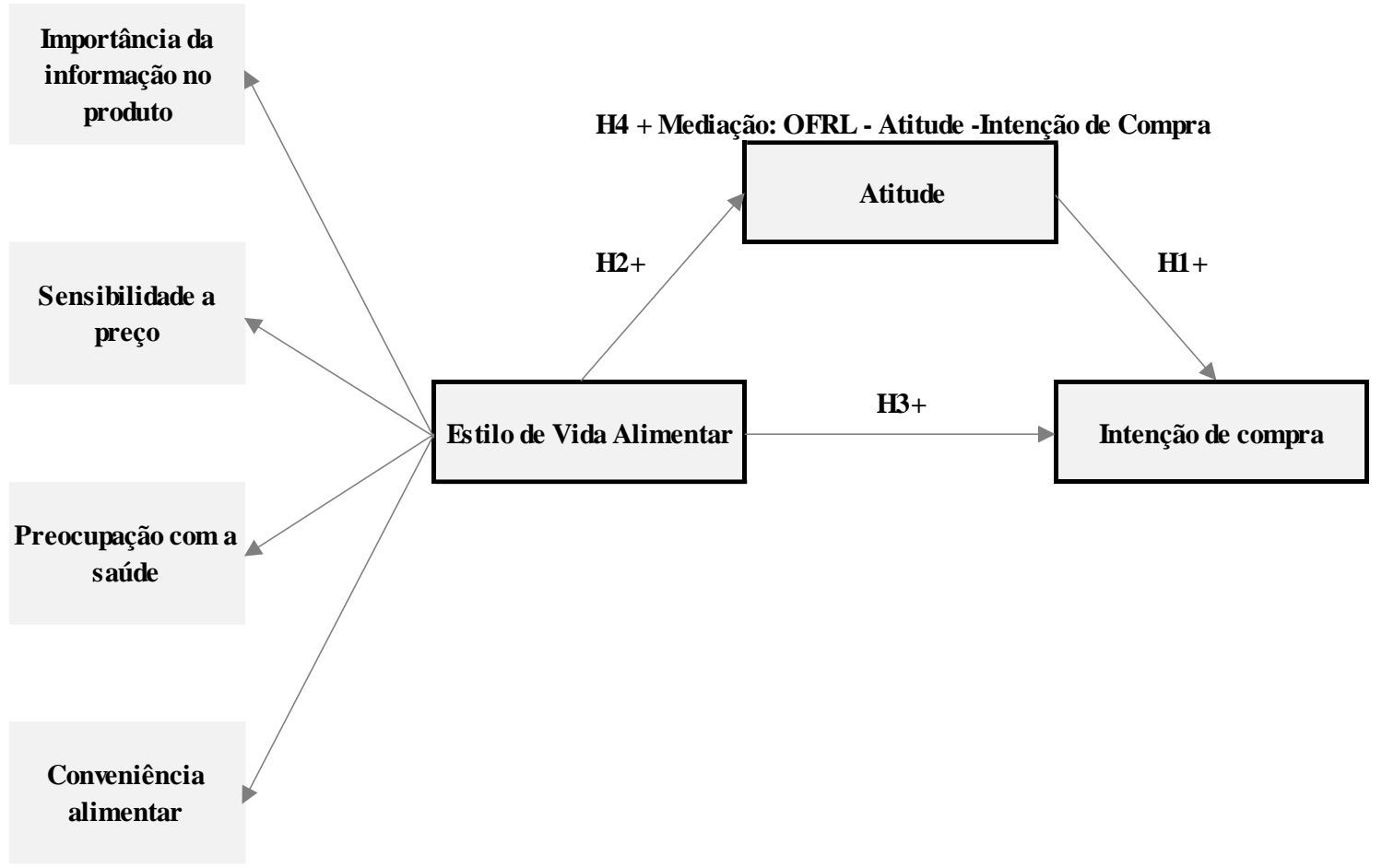

Fonte: Elaborado pelos autores. 
As escalas para medir as variáveis operacionais foram retiradas do FRL original de Grunert (1993) que, por sua vez, foi inspirado na Teoria da Cadeia de Meios-Fim (Gutman, 1982). Assim, a escala de estilo de vida foi construída a partir da conexão entre crenças, hábitos, preferências e valores. O modelo FRL conceitua o estilo de vida "como parte de um sistema hierárquico cognitivo-comportamental funcionando como um constructo organizador e orientador na vida de uma pessoa" (Thøgersen, 2017, p.2).

$\mathrm{Na}$ literatura, há afirmações teóricas que sugerem que o estilo de vida afeta o consumo de alimentos orgânicos (Oroian et al., 2017; Rana \& Paul, 2017; Thøgersen, 2017; Vera et al., 2016). A presente pesquisa objetivou medir esses impactos. Portanto, é importante avaliar se o estilo de vida relacionado à alimentação orgânica é um bom preditor da intenção de compra, como a hipótese H1 formaliza.

H1: O OFRL afeta positivamente a intenção de compra de alimentos orgânicos.

Considerando a relevância da atitude como preditor de comportamento, ela tem sido estudada em relação à intenção de compra de alimentos orgânicos. Visto que a literatura de alimentos orgânicos apresenta a atitude como o principal preditor da intenção de compra (Carfora et al., 2019; Watanabe, Alfinito \& Hamza, 2020), é importante saber como o OFRL influencia a atitude. Tudo indica que o estilo de vida tenha um impacto positivo na formação de uma atitude favorável em relação aos alimentos orgânicos. Deseja-se estimar o poder dessa relação.

H2: O OFRL afeta positivamente a atitude em relação aos alimentos orgânicos.

As mesmas razões que embasaram a hipótese anterior $(\mathrm{H} 2)$ servem também para apoiar a hipótese 3. O background da literatura da TPB sobre alimentos orgânicos confirma seu protagonismo para prever o comportamento futuro (Aertsens et al., 2009; Al-Swidi et al., 2014; Carfora et al., 2019; Chen \& Lobo, 2012; Harper \& Makatouni, 2002; Kuran \& Mihic, 2014; Meyer-Hofer et al., 2015; Tarkiainen \& Sundqvist, 2005; Thøgersen , 2017; Vukasovic, 2013; Yadav \& Pathak, 2016; Watanabe, Alfinito e Hamza, 2020; Wirth, Stanton \& Wiley, 2011). Portanto, é lógico supor que a atitude do consumidor brasileiro em relação aos alimentos orgânicos influencie a intenção de compra desse produto. Assim, haveria uma relação positiva entre a atitude dos consumidores em relação aos alimentos orgânicos e sua intenção de compra do produto.

H3: A atitude em relação aos alimentos orgânicos afeta positivamente a intenção de compra desses alimentos. 
Por fim, considerando a literatura básica sobre TPB e consumo orgânico e o papel que a atitude costuma desempenhar mediando a relação entre a variável independente e a variável dependente (Al-Swidi et al., 2014; Bagozzi et al., 1989; 2005; Katt \& Meixner, 2020; Kuran \& Mihic, 2014; Meyer-Hofer et al., 2015; Tarkiainen \& Sundqvist; Watanabe, Alfinito \& Hamza, 2020; Yadav \& Pathak, 2016), assume-se que, conforme a atitude do indivíduo se torna mais favorável ao consumo de alimentos orgânicos, suas percepções em relação ao estilo de vida dos alimentos pró-orgânicos passem a ter mais influência na intenção de compra.

H4: A influência do OFRL nas intenções de compra é mediada pela atitude em relação aos alimentos orgânicos.

\section{Métodos}

De acordo com as hipóteses e o modelo da pesquisa (Figura 1), para estudar o efeito do OFRL sobre a atitude e intenção de compra de alimentos orgânicos foi realizada uma pesquisa online com 651 consumidores de alimentos orgânicos.

\subsection{Participantes e procedimento de coleta de dados}

A pesquisa foi realizada entre 5 e 30 de maio de 2019, por meio de formulário Google Forms, para coletar as respostas. A população de interesse, para atingir os objetivos propostos por este estudo, foi de consumidores brasileiros com diferentes níveis de consumo de orgânicos. Como não existe uma estrutura amostral de consumidores de alimentos orgânicos no Brasil, não houve controle sobre a seleção da amostra. A questão filtro referiu-se à idade dos entrevistados, visto que todos os participantes deveriam ter mais de 18 anos e ter interesse em participar do estudo.

Para o cálculo amostral, seguindo as recomendações de Ringle, Silva e Bido (2014), foi utilizado o software G * Power 3.1, adotando as especificações determinadas por Cohen (1988), com um tamanho do efeito médio $(0,15)$ e um Poder de 0,80. A partir dessas premissas, o cálculo amostral resultou em um número mínimo de 68 respondentes, suficiente para detectar os efeitos desejados da Modelagem de Equações Estruturais com o Método dos Mínimos Quadrados Parciais (Partial Least Square - PLS). No total, 669 pessoas foram selecionadas pelo método de amostragem não probabilística, resultando em 651 questionários válidos.

Além disso, para avaliar possíveis vieses criados no processo de coleta de dados, calculamos a Variância do Método Comum (CMB sigla em inglês) de duas formas: a) Teste de fator único de Harman, que é realizado pelo cálculo de análise fatorial exploratória sem rotação 
e com um único fator. A variância extraída deve ser inferior a 40\% ("para ser ainda mais conservador". Ver Hair et. Al. 2019, p. 744) e b) no SEM-PLS incluindo uma variável de segunda ordem ligada às variáveis observadas e aos constructos originais. Este método foi sugerido por Podsakoff et al. (2003) e foi implementado por Liang et al. (2007). Na análise dos resultados, deve-se comparar os valores médios das AVE (Average Variance Extracted) de todos os originais com todos, devido ao método.

\subsection{Medidas e procedimentos}

Os itens da escala usada neste estudo foram adaptados de escalas previamente validadas em outros contextos (Grunert, Brunso, \& Bisp, 1995; Konuk, 2017; Nuttavuthisit \& Thøgersen, 2017). O questionário utilizou uma escala do tipo Likert (Anexo 1) com sete pontos para concordância / discordância, sendo 1 (um) para discordância total e 7 (sete) para concordância total. A validação em português das escalas de medida baseou-se em uma série de etapas (DeVellis, 2003; Hair Jr et al., 2019a): 1) definição clara de cada constructo; 2) revisão da literatura em busca de escalas validadas para os mesmos constructos; 3) as escalas adotadas foram submetidas à técnica de tradução e tradução reversa; 4) validação teórica ou de face - o instrumento de pesquisa foi avaliado e validado por três especialistas da área de marketing, que contribuíram para os ajustes das sentenças e a avaliação do seu enquadramento nos respectivos constructos propostos pela pesquisa; 5) validação semântica com possíveis respondentes (prétestes com 40 respondentes da amostra-alvo), por entrevista presencial; 6) validação estatística por análise confirmatória composta associada à modelagem de equações estruturais de mínimos quadrados parciais (PLS-SEM). A escala final, após o ajuste do modelo, encontra-se no Anexo 1.

Após o teste e avaliação da consistência interna do modelo proposto por Modelagem de Equações Estruturais (SEM) utilizando o software SmartPLS 2.0, foi feita a análise e avaliação do modelo estrutural, demonstrando como essas variáveis latentes relacionam-se entre si (Bido \& Silva, 2019). Os resultados do estudo são apresentados a seguir.

\section{Resultados}

\subsection{Características da amostra}

Após a triagem dos dados, com verificação dos casos de não resposta, foi realizado o teste de Mahalanobis. Os resultados apontaram menos de 3\% de casos extremos (outliers - 19 sujeitos), portanto a decisão foi pela manutenção destes respondentes. Além disso, o CMB 
(Common Method Bias) foi avaliado. Como resultado, obteve-se para o primeiro método um valor de variância explicada de $30,9 \%$, indicando que os dados podem ser considerados sem CMB. No segundo método (ver Tabela 1), pode-se concluir que o AVE (global) do modelo original explicou $65,7 \%$ dos dados e o AVE (global) devido ao método explicado apenas $0,9 \%$. Assim, é improvável que o método de coleta de dados gerou viés.

Também, o teste PK de Mardia foi realizado no software Lisrel 8.8. O teste baseado na distribuição qui-quadrado (assimetria e curtose) indicou valor de p menor que 0,0001 . Isso indicou que os dados não atenderam ao pressuposto de normalidade multivariada exigida pelo SEM baseado em covariância. Assim, foi utilizado SEM-PLS (baseado em correlação), que não necessita desse pressuposto (Hair et al., 2014).

\section{Tabela 1}

Cargas Fatoriais, Comunalidades e AVE Para o Modelo Original e o Modelo Devido ao Método

\begin{tabular}{|c|c|c|c|c|c|c|}
\hline Variável & $\begin{array}{c}\text { Carga fatorial } \\
\text { Modelo } \\
\text { Original }\end{array}$ & Comunalidades & AVE & $\begin{array}{c}\text { Carga } \\
\text { fatorial } \\
\text { Modelo } \\
\text { devido ao } \\
\text { Método }\end{array}$ & Comunalidades & AVE \\
\hline IPI_1 & 0,718 & 0,516 & & 0,082 & 0,007 & \\
\hline IPI_2 & 0,838 & 0,702 & 0,69 & $-0,001$ & 0,000 & 0,004 \\
\hline IPI_3 & 0,928 & 0,861 & & $-0,073$ & 0,005 & \\
\hline HLT_1 & 0,858 & 0,736 & & $-0,037$ & 0,001 & \\
\hline $\mathrm{HLT}_{2} 2$ & 0,654 & 0,428 & 0,673 & 0,204 & 0,042 & 0,025 \\
\hline HLT_3 & 0,925 & 0,856 & & $-0,177$ & 0,031 & \\
\hline$\overline{\text { PRC_1 }}$ & 0,827 & 0,684 & & $-0,042$ & 0,002 & \\
\hline PRC_2 & 0,742 & 0,551 & 0,643 & 0,087 & 0,008 & 0,004 \\
\hline PRC_3 & 0,833 & 0,694 & & $-0,043$ & 0,002 & \\
\hline $\mathrm{CNV}_{-} 1$ & 0,837 & 0,701 & & $-0,034$ & 0,001 & \\
\hline CNV_2 & 0,796 & 0,634 & 0,613 & 0,000 & 0,000 & 0,001 \\
\hline CNV_3 & 0,711 & 0,506 & & 0,038 & 0,001 & \\
\hline $\mathrm{ATT}_{-1} 1$ & 0,795 & 0,632 & & $-0,061$ & 0,004 & \\
\hline ATT_2 & 0,826 & 0,682 & & $-0,155$ & 0,024 & \\
\hline ATT_3 & 0,761 & 0,579 & 0,558 & $-0,068$ & 0,005 & 0,018 \\
\hline
\end{tabular}




\begin{tabular}{lcccccc}
\hline Variável & $\begin{array}{c}\text { Carga fatorial } \\
\text { Modelo } \\
\text { Original }\end{array}$ & Comunalidades & AVE & $\begin{array}{c}\text { Carga } \\
\text { fatorial } \\
\text { Modelo } \\
\text { devido ao } \\
\text { Método }\end{array}$ & Comunalidades & AVE \\
\hline ATT_4 & 0,784 & 0,615 & & 0,031 & 0,001 & \\
ATT_7 & 0,532 & 0,283 & & 0,235 & 0,055 & \\
PCI_1 & 0,883 & 0,780 & & $-0,038$ & 0,001 & \\
PCI_2 & 0,809 & 0,654 & 0,764 & 0,09 & 0,008 & 0,004 \\
PCI_3 & 0,927 & 0,859 & & $-0,055$ & 0,003 & \\
\hline Média & & $\mathbf{0 , 6 4 8}$ & $\mathbf{0 , 6 5 7}$ & & $\mathbf{0 , 0 1 0}$ & $\mathbf{0 , 0 0 9}$ \\
\hline
\end{tabular}

Fonte: Resultados da pesquisa (software SPSS versão 20.0).

Em relação às características dos participantes (Anexo 2), a amostra foi composta, majoritariamente, por mulheres $(73,6 \%)$ e as faixas etárias entre 25 e 54 anos correspondem a cerca de 66,36\% da amostra. Em termos de escolaridade, observa-se que a maioria dos respondentes possui pelo menos ensino superior $(89,86 \%)$ e cerca de $63,44 \%$ da amostra exerce alguma ocupação profissional remunerada. Considerando os hábitos de compra de alimentos orgânicos, 96\% são consumidores orgânicos, $48 \%$ indicaram comprar alimentos orgânicos pelo menos uma vez por semana (os outros 52\% em menor frequência), $49 \%$ afirmaram comprar alimentos em supermercados, lojas especializadas ou diretamente do produtor e $41 \%$ indicaram que compram produtos orgânicos em feiras livres.

Apesar do rigor metodológico adotado nesta pesquisa, ela apresenta limitações: a amostragem não probabilística por conveniência não permite a generalização dos resultados, nem a realização de inferências para toda a população. Entretanto, visto que o objetivo desta pesquisa é avaliar as possíveis relações de interdependência entre as variáveis estudadas, a técnica de amostragem por conveniência é aplicável (Hair et al., 2019).

A amostra apresenta concentração em consumidores do gênero feminino. Considerando que não houve controle amostral, este fato pode ser outra limitação da pesquisa. No entanto, a alta incidência feminina corrobora pesquisas anteriores (Barbosa, 2007; Medeiros 2017; Vasques, Clays \& Silva, 2008) que apresentam como justificativa para a concentração, questões culturais: majoritariamente, as mulheres estão mais atentas às questões de saúde familiar, bemestar, hábitos saudáveis e continuam sendo as responsáveis pela alimentação de todos os moradores da casa, desde a compra, escolha e preparo dos alimentos consumidos pela família (Bernardes et al. 2016; Porto \& Nardi, 2019). 


\subsection{Análise de dados: modelo de medição}

$\mathrm{Na}$ sequência, para testar a validade de constructo, foram analisadas as validades convergente e discriminante. A validade convergente foi analisada por meio da Variância Média Extraída (AVE). Na primeira rodada do algoritmo PLS, a análise revelou que apenas o constructo, ou variável latente (VL), Atitude apresentou itens com valores <0,50. Neste caso, eliminando as variáveis com as menores cargas fatoriais $(<0,50)$, na VL Atitude [ATT_5 $(0,142)$, ATT_6 $(0,488)$, ATT_8 $(0,068)$, ATT_9 $(0,069)$ e ATT_10 $(0,293)]$ e rodando o programa novamente, o critério de qualidade foi atingido, com todos as AVEs>0,50, garantindo validade convergente (Hair Jr et al., 2014). Os resultados são mostrados na tabela 2.

\section{Tabela 2}

Análise de Validade e Confiabilidade

\begin{tabular}{lcccccc}
\hline Validade Discriminante (Critério Fornell-Larcker) & $\mathbf{1}$ & $\mathbf{2}$ & $\mathbf{3}$ & $\mathbf{4}$ & $\mathbf{5}$ & $\mathbf{6}$ \\
\hline 1. Importância da informação de produto & $\mathbf{0 , 8 3 1}$ & & & & & \\
2. Critérios de preço & 0,347 & $\mathbf{0 , 8 0 0}$ & & & & \\
3. Saúde & 0,595 & 0,262 & $\mathbf{0 , 8 1 0 ^ { * }}$ & & & \\
4. Conveniência & 0,239 & 0,112 & 0,280 & $\mathbf{0 , 7 8 2}$ & & \\
5. Atitude & 0,316 & 0,206 & 0,492 & 0,104 & $\mathbf{0 , 7 3 6}^{*}$ & \\
6. Intenção de compra & 0,469 & 0,211 & 0,617 & 0,118 & 0,638 & $\mathbf{0 , 8 7 2}$ \\
& & & & & & \\
Alpha de Cronbach (AC) & 0,775 & 0,721 & 0,737 & 0,683 & 0,790 & 0,843 \\
Confiabilidade composta (CC) & 0,870 & 0,842 & 0,851 & 0,825 & 0,855 & 0,905 \\
Variância Média Extraída (AVE) & 0,691 & 0,640 & 0,656 & 0,612 & 0,542 & 0,761 \\
\hline
\end{tabular}

* Raiz quadrada da AVE

Fonte: Resultados da pesquisa.

Para avaliar a validade discriminante, que indica o quanto os constructos ou variáveis latentes são independentes uns dos outros (Hair Jr et al., 2014) foram utilizados os critérios de Chin (1998) e o critério de Fornell \& Larcker (1981). A avaliação pelo critério de Fornell e Larcker (1981) comprovou a validade discriminante: as raízes quadradas dos valores AVE de cada constructo são maiores que as correlações (de Pearson) entre constructos, conforme mostrado na Tabela 2. Destaca-se que o valor da correlação de intenção-atitude foi alto e próximo ao valor da raiz quadrada extraída da variância (0,638 e 0,736 respectivamente). Já o critério de Chin (1998), comprovou que os constructos ou variáveis latentes são diferentes entre si, uma vez que todos os indicadores (ou variáveis observáveis) apresentaram cargas fatoriais 
maiores em seus respectivos VL (ou constructos) do que em outros, todos os itens de Atitude e Intenção de Compra foram preservados (Anexo 3).

A análise da consistência interna - alfa de Cronbach (AC) e confiabilidade composta (CC) - mostrou que a amostra está livre de vieses e as respostas, como um todo, são confiáveis, pois os valores da AC são maiores que 0,60 e do CC os valores são maiores que 0,70, (Hair Jr et al., 2014), conforme mostrado na Tabela 2.

\subsection{Análise de dados: modelo de equação estrutural}

Após a análise do modelo de medição e os ajustes necessários, o modelo ajustado foi confirmado. A Figura 2 apresenta o modelo estrutural com os valores das correlações entre VO e VL; mostra o valor de $\mathrm{R}^{2}$ e mostra o coeficiente de caminho da regressão linear entre VL's.

O modelo ajustado apresenta boa qualidade estrutural: $\mathrm{R}^{2}$ com valores de $19 \%$ (atitude) e $51 \%$ (intenção de compra), conforme mostra a Figura 2. Em pesquisas realizadas nas áreas de ciências sociais e do comportamento, coeficientes $\mathrm{R}^{2}$ iguais a $13 \%$ podem ser classificados como de efeito médio e os de $26 \%$ como de grande efeito (Cohen, 1988), portanto o modelo apresenta grande efeito para os dois construtos endógenos.

\section{Figura 2}

Modelagem de Equações Estruturais: Modelo de Pesquisa Ajustado

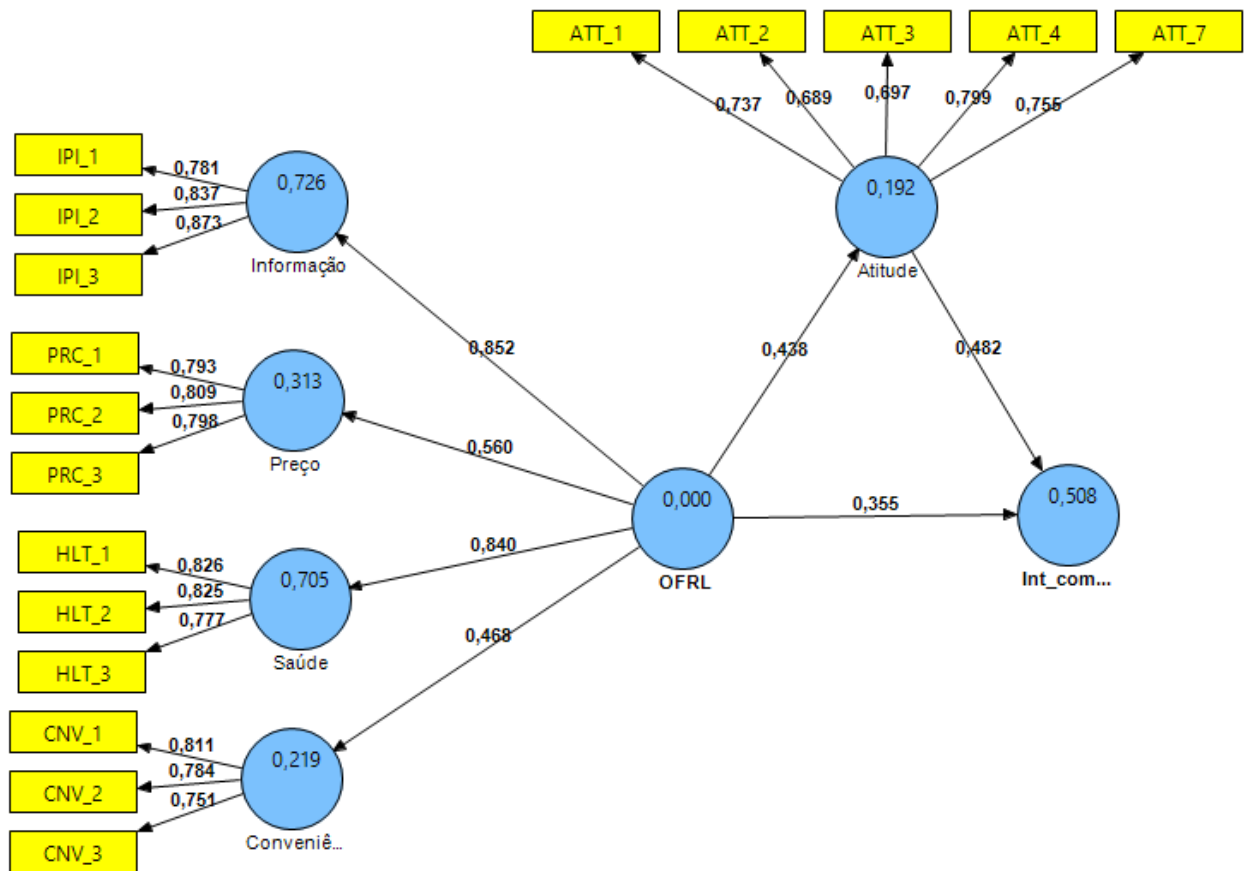

Legenda: Conveniê...=conveniência, ORFL=estilo de vida alimentar orgânico, Int_com.=intenção de compra

Fonte: Resultados da pesquisa (software PLS versão 2.0). 
A validade preditiva, um indicador da qualidade de ajuste do modelo, foi avaliada por meio do indicador de Stone-Geisser $\left(\mathrm{Q}^{2}\right)$. Os valores obtidos são maiores que zero para todas as variáveis (HAIR et al, 2014), portanto a qualidade do ajuste foi comprovada. A análise do tamanho do efeito, utilizando o Indicador de Cohen $\left(\mathrm{f}^{2}\right)$, mostrou que todos os constructos são úteis para o ajuste do modelo, pois todos apresentam valores considerados médio $(\geq 15 \%)$ ou grande ( $\geq 35 \%$ ), conforme mostrado na tabela 3 (Testes de hipóteses). Valores de 0,15 e 0,35 são considerados médios e grandes, respectivamente (Hair Jr et al, 2014).

\subsection{Análise de dados: testes de hipóteses}

A validade das relações (correlações e regressões) entre as variáveis foi realizada por meio de reamostragem (bootstraping) com 5.000 subamostras. O valor de referência para a análise é $\mathrm{t} \geq 1,96$ e a técnica é o teste $\mathrm{t}$ de Student (Hair Jr et al., 2014). Para todas as relações citadas, os valores ficaram maiores que 1,96 ( $\mathrm{p}<0,001)$, portanto, as correlações e os coeficientes de regressão são significantes. Os valores dos coeficientes de caminho (Гou $\beta$ coeficientes angulares das retas de regressão) variam entre .355 e .482 , indicando relações fortes e positivas (Hair Jr et al., 2014; Ringle, Silva \& Bido, 2014) (tabela 3).

\section{Tabela 3}

Testes de Hipóteses

\begin{tabular}{lccccc}
\hline Hipóteses & & $\begin{array}{c}\text { Coeficiente de } \\
\text { Caminho }\end{array}$ & $\mathbf{f}^{2}$ & Valor p & Conclusão \\
\hline ORL $\rightarrow$ PCI & H1(+) & 0,355 & 0,207 & $<0,001$ & Aceita \\
OFRL $\rightarrow$ ATT & H2(+) & 0,438 & 0,238 & $<0,001$ & Aceita \\
ATT $\rightarrow$ PCI & H3(+) & 0,482 & 0,382 & $<0,001$ & Aceita \\
OFRL $\rightarrow$ ATT $\rightarrow$ PCI & $\mathrm{H} 4(+)$ & 0,566 & - & $<0,05$ & Aceita \\
\hline
\end{tabular}

Legenda: ORFL: estilo de vida alimentar orgânico; PCI: i=ntenção de compra; ATT: atitude.

Fonte: Resultados da pesquisa.

Por fim, para confirmar a mediação expressa na hipótese 4, foi realizado o teste de Sobel. Os resultados apontam que a variável mediadora carrega significativamente a influência da variável independente para a variável dependente; ou seja, o efeito indireto do OFRL sobre a intenção de compra (PCI) mediada pela atitude (ATT) é significante [efeito total: 0,566; 
estatística do teste de Sobel: 9,23; relação é significante $(\mathrm{p}<0,05)]$. Significa que a atitude melhora o efeito do OFRL na intenção de compra.

\section{Discussão}

Os resultados obtidos com SEM-PLS são discutidos e aprofundados a seguir. Primeiramente, foi realizada uma análise das relações diretas entre as variáveis independentes e dependentes. A segunda etapa foi comparar os efeitos diretos e indiretos, analisando a mediação da relação OFRL- ATT - PCI. Dada a sua importância na composição da variável latente de segunda ordem, as relações entre o constructo de segunda ordem OFRL e suas quatro dimensões também foram testadas e analisadas.

A pesquisa forneceu evidências de que o estilo de vida explica o consumo orgânico. O modelo explicou $19 \%$ da variância da atitude e $51 \%$ da variância da intenção de compra. A análise do estilo de vida alimentar orgânico como preditor da atitude e da intenção de compra de alimentos orgânicos foi confirmada estatisticamente, corroborando estudos anteriores que indicam que estilo de vida, incluindo estilo de vida relacionado à alimentação, define o padrão de consumo que reflete as escolhas do indivíduo sobre como gastar seu tempo e dinheiro (Hughner et al., 2007; Pérez-Cueto, et al., 2010).

A hipótese H1 preconiza que o estilo de vida alimentar orgânico (ORFL) afeta a intenção de compra de alimentos orgânicos. A relação direta entre as duas variáveis tem um valor t de $10,351, \mathrm{p}<0,001$ e um coeficiente de caminho de 0,355 , indicando uma relação significante entre os constructos. Isso significa que o OFRL é um bom preditor da intenção de compra. Corroborando estudos anteriores (Oroian et al., 2017; Rana \& Paul, 2017; Thøgersen, 2017; Vera et al. 2016), este trabalho traz evidências empíricas dessa relação. Os resultados sugerem que, ao estimular um estilo de vida saudável, pode haver um estímulo indireto ao consumo de alimentos orgânicos.

A hipótese $\mathrm{H} 2$ também foi confirmada ( $\mathrm{p}<0,001$, valor $\mathrm{t}$ de 11,975 , coeficiente de caminho=0,438). Portanto, o estilo de vida relacionado aos alimentos orgânicos tem um efeito positivo na atitude em relação aos alimentos orgânicos e é mais forte do que o efeito na intenção. Os resultados corroboram estudos anteriores (Carfora et al., 2019; Watanabe, Alfinito \& Hamza, 2020), confirmam o papel do estilo de vida no consumo de alimentos orgânicos.

A hipótese H3 estabelece que a atitude em relação aos alimentos orgânicos afeta a intenção de compra desses alimentos. A relação entre as duas variáveis tem um valor t de 14,471 e um coeficiente de caminho de 0,482, indicando uma relação significante. A hipótese H3 foi 
confirmada e indica que a atitude também afeta a intenção de compra de alimentos orgânicos, corroborando os resultados de estudos anteriores (Al-Swidi et al., 2014; Katt e Meixner, 2020; Kuran \& Mihic, 2014; Meyer- Hofer et al., 2015; Watanabe, Alfinito e Hamza, 2020; Tarkiainen \& Sundqvist, 2005; Yadav e Pathak, 2016). Ou seja, quanto mais favorável for a atitude do consumidor em relação aos alimentos orgânicos, maior será a sua intenção de compra.

Por fim, a mediação expressa na hipótese 4 foi confirmada, corroborando a literatura (Bagozzi, 1989). O teste de Sobel foi realizado. Os resultados apontam que a variável mediadora é significante com relação à influência da variável independente para a variável dependente; ou seja, o efeito indireto do estilo de vida alimentar orgânico na intenção de compra mediada pela atitude é significante e complementar (efeito total: 0,566; estatística do teste de Sobel: 9,$23 ; \mathrm{p}<0,05)$. Isso significa que a função de mediação desempenhada pela atitude na relação entre o estilo de vida alimentar orgânico e a intenção de compra é positiva e significante e melhora a importância do estilo de vida relacionado aos alimentos orgânicos como um preditor da intenção de compra.

A literatura relata que o desenvolvimento da consciência acerca dos benefícios dos alimentos orgânicos, principalmente aqueles relacionados à saúde, dada a crescente preocupação dos consumidores com questões relacionadas a este aspecto, tendem a reforçar a atitude em relação a esses alimentos (Ergönül \& Ergönül, 2015; Oroian, et al., 2017). Nesta pesquisa, há evidências de que a atitude é um importante preditor da intenção de compra de alimentos orgânicos, além de desempenhar um papel mediador entre o estilo de vida relacionado aos alimentos orgânicos e a intenção de compra. Portanto, considerando o efeito direto do estilo de vida alimentar orgânico sobre a intenção de compra e o efeito indireto, ou seja, quando mediado pela atitude, pode-se dizer que o estilo de vida alimentar orgânico é um bom preditor de intenção de compra (efeito total: 0,566). Esse efeito ocorre parcialmente de forma direta, pela influência do OFRL na intenção de compra $(\mathrm{H} 1)$, e parcialmente pelo caminho indireto OFRL- atitude -intenção de compra (H4). Ambos os efeitos se complementam, de forma que, a partir do momento em que as crenças estimulam a formação de atitudes favoráveis ao consumo orgânico, o efeito do estilo de vida na intenção de compra é potencializado, por afetá-la direta e indiretamente.

As relações entre o constructo de segunda ordem OFRL e suas quatro dimensões também foram testadas e analisadas. As relações entre OFRL e informações sobre o produto $(0,852$; valor $\mathrm{p}<0,01)$, sensibilidade ao preço $(0,560$; valor $\mathrm{p}<0,01)$ e preocupação com a saúde 
$(0,840$; valor $\mathrm{p}<0,01)$ e conveniência $(0,468$; valor $\mathrm{p}<0,01)$ foram todos significantes a $1 \%$, mas com magnitudes diferentes. Observa-se que algumas das dimensões utilizadas para compor o OFRL são mais relevantes para impactar a atitude e intenção de consumir alimentos orgânicos do que outras. Assim, os resultados alcançados com as variáveis operacionais serão discutidos a seguir, em comparação com a literatura.

A variável "importância da informação do produto" apresentou a maior associação com o OFRL (o maior coeficiente de correlação $=0,852$; Confiabilidade composta $(\mathrm{CC})=0,870$ ). As informações do produto são capazes de identificá-lo como um alimento orgânico, além de permitir a comparação entre orgânico e não orgânico. Sua importância para o consumo do produto é vital. Esse resultado corrobora estudos anteriores que indicam que os consumidores associam o consumo de alimentos orgânicos ao alto envolvimento com a experiência alimentar e ao interesse crescente por todos os aspectos da compra de alimentos, principalmente com as informações do produto (Fang \& Lee, 2009; Grunert, Brunso, \& Bisp, 1993; Grunert, Brunso, \& Bisp, 1995; Ryan et al., 2004). Além disso, a rotulagem de alimentos é uma estratégia importante para auxiliar os consumidores durante o processo de escolha de alimentos e pode ser uma aliada para o desenvolvimento do mercado orgânico (Gottschalk \& Leistner, 2012; Lim, Yong \& Suryadi, 2014; Prada, Garrido, \& Rodrigues, 2017; Sangkumchaliang \& Huang, 2012).

A dimensão saúde apresentou a segunda maior associação com o OFRL (coeficiente de caminho =0,840; $\mathrm{CC}=0,851)$. Ao lado da "importância da informação do produto", a dimensão "saúde" auxilia na formação de um estilo de vida relacionado à alimentação capaz de prever a atitude e a intenção de compra de alimentos orgânicos. Isso porque consumidores preocupados com a saúde tendem a demonstrar uma preferência maior por esses alimentos (Hemmerling, Hamm \& Spiller, 2015; Oroian, et al., 2017; Rödiger \& Hamm, 2015).

A variável "sensibilidade ao preço" produziu um coeficiente de caminho de 0,560 e um CC de 0,842. O critério de preço é uma variável chave, pois, de acordo com a literatura, o preço desempenha um papel significativo no processo de tomada de decisão e expressa uma das barreiras mais relevantes para o consumo de alimentos orgânicos (Aertsens, Verbeke, Mondelaers, \& Huylenbroeck, 2009; Rödiger \& Hamm, 2015; Shin, 2018). A escala adotada mede a busca por promoções e a atenção dada às possíveis variações de preços. À primeira vista, poder-se-ia supor que tais comportamentos não seriam compatíveis com o consumo de alimentos orgânicos. No entanto, o resultado pode sugerir uma tendência comportamental, que leva os consumidores da classe média a buscar produtos ou marcas mais baratas, em categorias 
de baixo envolvimento, para que possam gastar mais com produtos e marcas, em categorias de alto envolvimento. Essa tendência vem sendo denominada "trading up/trading down" (Silverstein, Fiske \& Butman, 2008).

De modo direto, a tendência explica que é possível ser sensível ao preço em algumas categorias e não em outras. Com base nela, poder-se-ia hipotetizar comportamento semelhante no consumo de alimentos orgânicos. Assim, o consumidor orgânico poderia estar engajado com a alimentação e disposto a pagar mais para ter uma alimentação saudável. O comportamento de buscar promoções e ficar atento às variações de preços pode indicar a possibilidade de fazer substituições, por exemplo, gastar menos com produtos de limpeza doméstica, para gastar mais com alimentos mais saudáveis. Portanto, não se pode concluir que o critério de preço seja uma barreira ao consumo orgânico.

Por fim, a dimensão "conveniência", cuja escala mede a conveniência no preparo dos alimentos, apresentou a menor associação com o OFRL (coeficiente de caminho = 0,468; CC $=0,825)$. Mesmo tratada de forma reversa, por apresentar sentido oposto ao consumo de alimentos orgânicos, a escala de conveniência não foi muito eficiente como dimensão do estilo de vida para moldar a atitude e intenção de compra de alimentos orgânicos.

\section{Conclusão}

O objetivo principal deste artigo foi analisar o efeito dos determinantes do estilo de vida relacionados à alimentação orgânica sobre a atitude e intenção de compra de alimentos orgânicos, por consumidores brasileiros. Os resultados apresentaram evidências de que o estilo de vida relacionado à alimentação orgânica, mediado ou não pela atitude, é um bom preditor da intenção de compra de alimentos orgânicos. A contribuição teórica principal deste estudo, isto é, a originalidade da proposta, é ter sido o primeiro a propor um constructo multidimensional para mensurar o estilo de vida relacionado aos alimentos orgânicos no contexto brasileiro e seu impacto na atitude e intenção de compra desse alimento, introduzindo uma estrutura conceitual e modelando os constructos, por meio de equações estruturais.

Além disso, os resultados confirmaram a relação entre a atitude e a intenção de compra mostrando que quanto mais favorável a atitude do consumidor em relação aos alimentos orgânicos, maior sua intenção de compra. Assim, o estímulo ao consumo depende também da consciência dos benefícios dos alimentos orgânicos, que tendem a reforçar a atitude em relação a esses alimentos. Por sua vez, a teoria indica que a consciência possibilitada pelos processos de comunicação é um componente da formação de atitudes, o que reforça a conclusão anterior. 
Os resultados evidenciaram a importância das informações sobre o produto no processo de decisão e compra de alimentos orgânicos, corroborando estudos anteriores.

O presente artigo traz implicações gerenciais ao revelar o papel fundamental da informação no estilo de vida relacionado à alimentação orgânica e na formação de uma atitude frente ao consumo de orgânicos, no contexto brasileiro. Ampliando o escopo desses resultados, pode-se inferir que, no mercado brasileiro, proporcionar informações sobre os benefícios dos alimentos orgânicos é ainda mais importante, porque o segmento orgânico ainda é um nicho e o consumidor tem mais dúvidas, do que certezas, sobre o processo produtivo e as vantagens dos alimentos orgânicos. Assim, os resultados sugerem uma grande oportunidade para a rede se unir e trabalhar a comunicação institucional, de forma mais efetiva, para a conscientização sobre os benefícios à saúde. É provável que quanto mais o consumidor brasileiro perceber os benefícios que os alimentos orgânicos proporcionam à sua saúde, mais favorável será ao consumo desses alimentos. Essa constatação é importante para estimular o crescimento do mercado de alimentos orgânicos no Brasil, hoje ainda embrionário.

Apesar do cuidado metodológico e rigor adotados na sua condução, a pesquisa apresenta limitações. O uso de amostragem não-probabilística por conveniência não permite a generalização dos resultados. Além disso, a amostra apresenta concentração de consumidoras do gênero feminino, o que parece refletir o perfil do comprador orgânico.

Este artigo sugere que estudos futuros analisem, comparativamente, diferentes categorias de alimentos orgânicos, a fim de avaliar se o impacto das dimensões dos alimentos orgânicos relacionados ao estilo de vida, especialmente a importância da informação sobre o produto e saúde, sobre a atitude e a intenção de compra se repetem em todos os tipos de alimentos ou se eles variam por categoria. Nesse contexto, outro aspecto relevante é avaliar se os consumidores apresentam diferentes níveis de atitude e intenção de compra em relação às diferentes macro categorias de produtos, incidindo principalmente na distinção entre alimentos orgânicos frescos e processados. É possível sugerir que pesquisas futuras utilizem amostras mais heterogêneas, permitindo identificar a estabilidade dos resultados observados.

\section{Referências}

ABRAS. Associação Brasileira de Supermercados Setor de orgânicos cresce $30 \%$ no Brasil em 2020. (10 fev 2021). https://www.abras.com.br/clipping/geral/72392/setor-deorganicos-cresce-30-no-brasil-em-2020. 
Achilleas, K., \& Anastasios, S. (2008). Marketing aspects of quality assurance systems: the organic food sector case. British Food Journal, 110(8), pp. 829-839. https://doi.org/10.1108/00070700810893359

Aertsens, J., Verbeke, W., Mondelaers, K., \& Huylenbroeck, G. V. (2009). Personal determinants of organic food consumption: a review. British Food Journal, 111(10), pp. 1140-1167. https://doi.org/10.1108/00070700910992961

Ajzen, I. (1991). The theory of planned behavior. Organizational Behavior and Human Decision Processes, 50, pp. 179-211. https://doi.org/10.1016/0749-5978(91)90020-T

Ajzen, I., \& Fishbein, M. (1973). Attitudinal and normative variables as predictors of specific behavior. Journal of Personality and Social Psychology, 27, pp. 41-57. https://doi.org/10.1037/h0034440

Al-Swidi, A., Huque, S. M., Hafeez, M. H., \& Shariff, M. M. (2014). The role of subjective norms in theory of planned behavior in the context of organic food consumption. British Food Journal, 116(10), pp. 1561-1580. https://doi.org/10.1108/BFJ-05-2013-0105

Anderson Jr, W. T., \& Golden, L. L. (1984). Lifestyle and psychographics: A critical review and recommendation. Advances in consumer research, 11(1), pp. 405-411.

Aschemann-Witzel, J., \& Aagaard, E. M. (2014). Elaborating on the attitude-behaviour gap regarding organic products: young Danish consumers and in-store food choice. International Journal of Consumer Studies, 38(5), pp. 550-558. https://doi.org/10.1111/ijcs.12115

Barbosa, S. C. et al. Perfil do consumidor e oscilações de preços de produtos agroecológicos. Revista de Pesquisa Agropecuária, Goiânia-GO, v. 41, n. 4, p. 602-609, Out./Dez. 2011. https://doi.org/10.5216/pat.v41i4.11854

Bell, W. (1958), "Social choice, life style, and suburban residence", in Dobriner, W.M. (Ed.), The Suburban Community, G.P. Putnam's Sons, New York, NY, pp. 225-242.

Bagozzi, R.P., Baumgartner, J. and Yi, Y. (1989), “An investigation into the role of intentions as mediators of the attitude-behavior relationship", Journal of Economic Psychology, 10, 35-62. https://doi.org/10.1016/0167-4870(89)90056-1

Bernardes, A. F. M., Silva, C. G., \& Frutuoso, M. F. P. (2016). Alimentação saudável, cuidado e gênero: percepções de homens e mulheres da zona noroeste de Santos-SP. Demetra: Alimentação, Nutrição \& Saúde, 11(3), 559-573. https://doi.org/10.12957/demetra.2016.22334

Bido, D. S., \& Silva, D. (2019). SmartPLS 3: specification, estimation, evaluation and reporting. Administração: Ensino e Pesquisa, 20(2), pp 465-513. https://doi.org/10.1305 8/raep.2 019.v20n2 .1545

Britwum, K., Bernard, J. C., \& Albrecht, S. E. (2020) Importance influence beliefs in organic food attributes? Food Quality and Preference, pp. 2411-2502.

https://doi.org/10.1016/j.foodqual.2020.104056 
Capps, O., Tedford, J. R., \& Havlicek, J. (1985). Household Demand for Convenience and Nonconvenience Foods. American Journal of Agricultural Economics, 67, pp. 862-869. https://doi.org/10.2307/1241827

Carfora, V., Cavallo, C., Caso, D., Del Giudice, T., De Devitiis, B., Viscecchia, R., \& Cicia, G. (2019). Explaining consumer purchase behavior for organic milk: Including trust and green self-identity within the theory of planned behavior. Food Quality and Preference, 76, 1-9. https://doi.org/10.1016/j.foodqual.2019.03.006

Chen, J., \& Lobo, A. (2012). Organic food products in China: determinants of consumers' purchase intentions. The International Review of Retail, Distribution and Consumer Research, 22(3), pp. 293-314. . https://doi.org/10.1080/09593969.2012.682596

Chin, W. W. (1998). The partial least squares approach for structural equation modeling. Modern methods for business research. Mahwah: Lawrence Erlbaum Associates Publishers.

Chryssochoidis, G. (2000). Repercussions of consumer confusion for late introduced differentiated products. European Journal of Marketing, 34(5/6), pp. 705-722. https://doi.org/10.1108/03090560010321992

Cohen, J. (1988). Statistical Power Analysis for the Behavioral Sciences. New York: Psychology Press.

Devellis, R. F. (2003). Scale development: theory and applications. Thousand Oaks: Sage Publications, 2003.

Ergönül, B., \& Ergönül, P. G. (2015). Consumer motivation for organic food consumption. Emirates Journal of Food and Agriculture, 27(5), pp. 416-422. https://doi.org/10.9755/ejfa.2015.04.034

Essoussi, L. H., \& Zahaf, M. (2008). Decision making process of community organic food consumers: an exploratory study. Journal of Consumer Marketing, 25(2), pp. 95-104. https://doi.org/10.1108/07363760810858837

Fang, C. H., \& Lee, H. J. (2009). Food-related lifestyle segments in Taiwan: application of the food-related lifestyle instrument. American Journal of Applied Sciences, 6(12), pp. 2036-2042. https://doi.org/10.3844/ajassp.2009.2036.2042

Fornell, C., \& Larcker, D. F. (1981). Evaluating structural equation models with unobservable variables and measurement error. National Institute of Industrial Engineering. Mumbai.

Gerrard, C., Janssen, M., Smith, L. H., \& Padel, S. (2013). UK consumer reactions to organic certification logos. British Food Journal, 115(5), pp. 727-742. https://doi.org/10.1108/00070701311331517

Goetzke, B. I., \& Spiller, A. (2014). Health-improving lifestyles of organic and functional food consumers. British Food Journal, 116(3), 510-526. https://doi.org/10.1108/BFJ-032012-0073 
Gonzalez, J. A. (2012). World economic crisis impact on organic products consumption: Costa Rica, 2009. British Food Journal, 114(1), pp. 5-18. https://doi.org/10.1108/00070701211197338

Gottschalk, I., \& Leistner, T. (2012). Consumer reactions to the availability of organic food in discount supermarkets. International Journal of Consumer Studies, 37(2), pp. 136-142. https://doi.org/10.1111/j.1470-6431.2012.01101.x

Grunert, K. G. (1993). Towards a concept of food-related lifestyle. Appetite, 21, pp. 151-155. https://doi.org/10.1016/0195-6663(93)90007-7

Grunert, K. G., Bruns $\varnothing$, K., \& Bisp, S. (1993). Food-related lifestyle: development of a crossculturally valid instrument for market surveillance. Århus, Denmark: MAPP.

Grunert, K. G., Brunsø, K., \& Bisp, S. (1995). Food-related life style in Great Britain. Aarhus: Mapp Project.

Gutman, J. (1982). A means-end chain model based on consumer categorization processes. Journal of marketing, 46(2), 60-72. https://doi.org/10.2307/3203341

Hair, J.F., Black, W.C., B.J., \& Anderson, R.E. (2019). Multivariate data analysis. 9th ed. Hampshire: Cengage Learning.

Hair, J. F., Gabriel, M. L., da Silva, D., \& Junior, S. B. (2019a). Development and validation of attitudes measurement scales: fundamental and practical aspects. RAUSP Management Journal, 54(4), 490-507. https://doi.org/10.1108/RAUSP-05-2019-0098

Hair Jr, J. F., Hult, G. T., Ringle, C. M., \& Sarstedt, M. A. (2014). Primer on Partial Least Squares Structural Equation Modeling (PLS-SEM). Thousand Oaks: Sage Publications.

Harper, G. C., \& Makatouni, A. (2002). Consumer perception of organic food production and farm animal welfare. British Food Journal, 104(3/4/5), 287-299. https://doi.org/10.1108/00070700210425723

Hasselbach, J. L., \& Roosen, J. (2015). Consumer heterogeneity in the willingness to pay for local and organic food. Journal of Food Products Marketing, 21(6), 608-625. https://doi.org/10.1080/10454446.2014.885866

Havighurst, R. J., \& Feigenbaum, K. (1959). Leisure and life-style. American Journal of Sociology, 64(4), 396-404. https://doi.org/10.1086/222500

Hemmerling, S., Hamm, U., \& Spiller, A. (2015). Consumption behaviour regarding organic food from a marketing perspective: a literature review. Organic Agriculture, 5(4), pp. 277 313. https://doi.org/10.1007/s13165-015-0109-3

Henseler, J., \& Sarstedt, M. (2013). Goodness-of-fit indices for partial least squares path modeling. Computational statistics, 28(2), 565-580. https://doi.org/10.1007/s00180-0120317-1 
Homburg, C., Koschate, N., \& Hoyer, W. D. (2005). Do satisfied customers really pay more? A study of the relationship between customer satisfaction and willingness to pay. Journal of Marketing, 69(2), 84-96. https://doi.org/10.1509/jmkg.69.2.84.60760

Hughner, R. S., McDonagh, P., Prothero, A., Shultz, C. J., \& Stanton, J. (2007). Who are organic food consumers? A compilation and review of why people purchase organic food. Journal of Consumer Behaviour, 6, 94-110. https://doi.org/10.1002/cb.210

Janssen, M. (2018). Determinants of organic food purchases: Evidence from household panel data. Food Quality and Preference, 68, 19-28. https://doi.org/10.1016/j.foodqual.2018.02.002

Katt, F., \& Meixner, O. (2020). A systematic review of drivers influencing consumer willingness to pay for organic food. Trends in Food Science \& Technology, 100, 374-388. https://doi.org/10.1016/j.tifs.2020.04.029

Konuk, F. A. (2017). Price fairness, satisfaction, and trust as antecedents of purchase intentions towards organic food. Journal of Consumer Behaviour, 17(2), 141-148. https://doi.org/10.1002/cb.1697

Kuran, L. M., \& Mihic, M. (2014). Applying the theory of planned behavior in the purchase of organic food. Trziste, 26, 179-197.

Liang, H., Saraf, N., Hu, Q., \& Xue, Y. (2007). Assimilation of enterprise systems: the effect of institutional pressures and the mediating role of top management. MIS quarterly, 59-87. https://doi.org/10.2307/25148781

Lim, W. M., Yong, J. L., \& Suryadi, K. (2014). Consumers' perceived value and willingness to purchase organic food. Journal of Global Marketing, 27(5), 298-307. https://doi.org/10.1080/08911762.2014.931501

McBroom, W. H., \& Reed, F. W. (1992). Towards conceptualization of Attitude-Behavior Consistency. Social Psychology Quarterly, 55(2), 205-216. https://doi.org/10.2307/2786946

Medeiros, B. E., Marconato, T., \& de Souza, A. E. (2017). Estudo bibliométrico sobre a motivação para o consumo de produtos orgânicos. Revista Cadernos de Economia, 21(38), 74-88.

Meyer-Hofer, M. V., Olea-Jaik, E., Padilla-Bravo, C. A., \& Spillera, A. (2015). Mature and Emerging Organic Markets: Modelling Consumer Attitude and Behaviour With Partial Least Square Approach. Journal of Food Products Marketing, 21(6), 626-653. https://doi.org/10.1080/10454446.2014.949971

Mondelaers, K., Verbeke, W., \& Huylenbroeck, G. V. (2009). Importance of health and environment as quality traits in the buying decision of organic products. British Food Journal, 111(10), 1120-1139. https://doi.org/10.1108/00070700910992952

Nuttavuthisit, K., \& Thøgersen, J. (2017). The importance of consumer trust for the emergence of a market for green products: The case of organic food. Journal of Business Ethics, 140(2), 323-337. https://doi.org/10.1007/s10551-015-2690-5 
Oroian, C. F., Safirescu, C. O., Harun, R., Chiciudean, G. O., Arion, F. H., Muresan, I. C., \& Bordeanu, B. M. (2017). Consumers' attitudes towards organic products and sustainable development: a case study of Romania. Sustainability, 9(9), 1559-1573. https://doi.org/10.3390/su9091559

Paul, J., \& Rana, J. (2012). Consumer behavior and purchase intention for organic food. Journal of Consumer Marketing, 29(6), 412-422. https://doi.org/10.1108/07363761211259223

Pérez-Cueto, F. J., Verbeke, W., De Barcellos, M. D., Kehagia, O., Chryssochoidis, G. S., \& Grunert, K. (2010). Food-related lifestyles and their association to obesity in five European countries. Appetite, 54(1), 156-162. https://doi.org/10.1016/j.appet.2009.10.001

Piqueras-Fiszman, B., \& Spence, C. (2015). Sensory expectations based on product-extrinsic food cues: An interdisciplinary review of the empirical evidence and theoretical accounts. Food Quality and Preference, 40, 165-179. https://doi.org/10.1016/j.foodqual.2014.09.013

Plummer, J. T. (1974) The concept and application of life style segmentation. Journal of Marketing, 38(1), 33-37. https://doi.org/10.2307/1250164

Podsakoff, P. M., MacKenzie, S. B., Lee, J. Y., \& Podsakoff, N. P. (2003). Common method biases in behavioral research: a critical review of the literature and recommended remedies. Journal of applied psychology, 88(5), 879-903. https://doi.org/10.1037/0021-9010.88.5.879

Porto, B. R., \& Nordi, W. M. (2019). Caracterização de consumidores de alimentos orgânicos: uma pesquisa quantitativa realizada em rede social. Caderno de Ciências Agrárias, 11, 1-9. https://doi.org/10.35699/2447-6218.2019.15926

Prada, M., Garrido, M. V., \& Rodrigues, D. (2017). Lost in processing? Perceived healthfulness, taste and caloric content of whole and processed organic food. Appetite, 114, 175-186. https://doi.org/10.1016/j.appet.2017.03.031

Rana, J., \& Paul, J. (2017). Consumer behavior and purchase intention for organic food: a review and research agenda. Journal of Retailing and Consumer Services, 38, 157-165. https://doi.org/10.1016/j.jretconser.2017.06.004

Rainwater, L., Coleman, R.P., \& Handel, G. (1959), Workingman's wife: her personality, world and life style, New York: Oceana Publ.

Reid, M., Li, E., Bruwer, J., \& Grunert, K. (2001). Food-related lifestyles in a cross-cultural context: comparing Australia with Singapore, Britain, France and Denmark. Journal of Food Products Marketing, 7(4), 57-75. https://doi.org/10.1300/J038v07n04_05

Ringle, C. M., Silva, D., \& Bido, D. S. (2014). Structural Equation Modeling with the Smartpls. Brazilian Journal Of Marketing, 13(2), 54-71. https://doi.org/10.5585/remark.v13i2.2717

Rödiger, M., \& Hamm, U. (2015). How are organic food prices affecting consumer behaviour? A review. Food Quality and Preference, 43, 10-20.

https://doi.org/10.1016/j.foodqual.2015.02.002 
Rödiger, M., Plaßmann, S., \& Hamm, U. (2016). Organic consumers’ price knowledge, willingness-to-pay and purchase decision. British Food Journal, 118(11). https://doi.org/10.1108/BFJ-04-2016-0164

Ryan, I., Cowan, C., McCarthy, M., \& O'sullivan, C. (2004). Segmenting Irish food consumers using the food-related lifestyle instrument. Journal of International Food \& Agribusiness Marketing, 16(1), pp. 89-114. https://doi.org/10.1300/J047v16n01_06

Sangkumchaliang, P., \& Huang, W. C. (2012). Consumers' perceptions and attitudes of organic food products in Northern Thailand. International Food and Agribusiness Management Review, 15(1), 87-102. https://doi.org/10.22004/ag.econ.120860

Savelli, E., Murmura, F., Liberatore, L., Casolani, N., \& Bravi, L. (2017). Food habits and attitudes towards food quality among young students. International Journal of Quality and Service Sciences, 9(3/4), 456-468. https://doi.org/10.1108/IJQSS-02-2017-0011

Shin, Y. H. (2018). The theory of planned behavior and the norm activation model approach to consumer behavior regarding organic menus. International Journal of Hospitality Management, 69, 21-29. https://doi.org/10.1016/j.ijhm.2017.10.011

Silverstein, M. J., Fiske, N., \& Butman, J. (2008). Trading Up: why consumers want new luxury goods--and how companies create them. New York: Penguin.

Sobel, M. E. (1982). Asymptotic confidence intervals for indirect effects in structural equation models. Sociological Methodology, 13, 290-312. https://doi.org/10.2307/270723

Tarkiainen, A., \& Sundqvist, S. (2005). Subjective norms, attitudes and intentions of finnish consumers in buying organic food. British Food Journal, 107(11), 808-822. https://doi.org/10.1108/00070700510629760

Thøgersen, J. (2017). Sustainable food consumption in the nexus between national context and private lifestyle: A multi-level study. Food Quality and Preference, 55, 16-25. https://doi.org/10.1016/j.foodqual.2016.08.006

Vásquez, S. F., de Souza Barros, J. D., \& da Silva, M. D. F. P. (2008). Agricultura orgânica: caracterização do seu consumidor em Cajazeiras - PB. Revista Verde de Agroecologia e Desenvolvimento Sustentável, 3(1), 152 - 158.

Vera, J. M., Pérez, C. E., Puig, M. A., \& Montero-Vicente, L. (2016). Consumer segmentation based on food-related lifestyles and analysis of rabbit meat consumption. World Rabbit Science, 24(3), 169-182. https://doi.org/10.4995/wrs.2016.4229

Vukasovic, T. (2013). Attitude towards organic meat: an empirical investigation on West Balkans Countries (WBC) consumers. World's Poultry Science Journal, 69(3), 527-540. https://doi.org/10.1017/S004393391300055X

Watanabe, E. A., Alfinito, S. C., \& Hamza, K. M. (2020). Perceived value, trust and purchase intention of organic food: a study with Brazilian consumers. British Food Journal, 122(4), 1070-1184. https://doi.org/10.1108/bfj-05-2019-0363 
Wekeza, S. V.; Sibanda, M. (2019). Factors influencing consumer purchase intentions of organically grown products in shelly centre, port shepstone, South Africa. International journal of environmental research and public health, 16(6), 956.

https://doi.org/10.3390/ijerph16060956

Wirth, F. F., Stanton, J. L., \& Wiley, J. B. (2011). The relative importance of search versus credence product attributes: Organic and locally grown. Agricultural and Resource Economics Review, 40(1), 48-62. https://doi.org/10.1017/S1068280500004512

Yadav, R., \& Pathak, G. S. (2016). Intention to purchase organic food among young consumers: evidences from a developing nation. Appetite, 96, 122-128.

https://doi.org/10.1016/j.appet.2015.09.017

Yazdanpanah, M., Forouzani, M., \& Hojjati, M. (2015). Willingness of Iranian young adults to eat organic food: Application of the Health Belief Model. Food Quality and Preference, 41, 75-83. https://doi.org/10.1016/j.foodqual.2014.11.012

Zanoli, R., \& Naspetti, S. (2002). Consumer motivations in the purchase of organic food: A means-end approach. British food journal. 104 (8), 643-653.

https://doi.org/10.1108/00070700210425930 


\section{Anexo 1}

\section{Escala usada na pesquisa}

\begin{tabular}{|c|c|c|}
\hline Constructo & Rótulo & Item \\
\hline \multirow{3}{*}{$\begin{array}{l}\text { Importância da } \\
\text { informação do } \\
\text { produto } \\
\text { (IPI) }\end{array}$} & IPI_1 & $\begin{array}{l}\text { Para mim, as informações do produto são de grande importância. Eu preciso saber o que o } \\
\text { produto contém. }\end{array}$ \\
\hline & IPI_2 & Comparo os rótulos para selecionar os alimentos mais nutritivos. \\
\hline & IPI_3 & Eu comparo os rótulos de informações do produto para decidir qual marca experimentar \\
\hline \multirow{3}{*}{$\begin{array}{l}\text { Critério de } \\
\text { Preço } \\
\text { (PRC) }\end{array}$} & PRC_1 & Sempre verifico os preços, mesmo em itens de baixo valor. \\
\hline & PRC_2 & Percebo quando os produtos que compro mudam regularmente de preço. \\
\hline & PRC_3 & $\begin{array}{l}\text { Presto atenção aos anúncios de promoções de lojas no jornal e pretendo aproveitá-los } \\
\text { quando for às compras. }\end{array}$ \\
\hline \multirow{3}{*}{$\begin{array}{l}\text { Saúde } \\
\text { (HLT) }\end{array}$} & HLT_1 & Prefiro comprar produtos naturais, ou seja, produtos sem conservantes. \\
\hline & HLT_2 & Para mim, a naturalidade da comida que compro é uma qualidade importante. \\
\hline & HLT_3 & Tento evitar produtos alimentícios com aditivos. \\
\hline \multirow{3}{*}{$\begin{array}{l}\text { Conveniência } \\
\text { (CNV) }\end{array}$} & CNV_1 & Eu uso muitos alimentos congelados na minha cozinha. \\
\hline & CNV_2 & Usamos muitos alimentos prontos para consumo em nossa casa. \\
\hline & CNV_3 & Eu uso muitas misturas, por exemplo misturas para bolos e sopas em pó. \\
\hline \multirow{10}{*}{$\begin{array}{l}\text { Atitude } \\
\text { (ATT) }\end{array}$} & ATT_1 & Os alimentos orgânicos são produzidos de uma forma que é melhor para o meio ambiente. \\
\hline & ATT_2 & Alimentos orgânicos são naturais. \\
\hline & ATT_3 & Os alimentos orgânicos não contêm pesticidas. \\
\hline & ATT_4 & Alimentos orgânicos são mais saudáveis. \\
\hline & ATT 5* & Produtos vendidos como orgânicos não são realmente orgânicos. \\
\hline & ATT 6* & Orgânico é apenas um truque de marketing. \\
\hline & ATT_7 & Os alimentos orgânicos têm um sabor melhor. \\
\hline & ATT 8* & O alimento orgânico expira mais rápido. \\
\hline & ATT 9* & Alimentos processados podem ser orgânicos. \\
\hline & ATT 10* & Alimentos orgânicos podem ser baratos. \\
\hline \multirow{3}{*}{$\begin{array}{l}\text { Intenção de } \\
\text { Compra } \\
\text { (PCI) }\end{array}$} & PCI_1 & Estou disposto a comprar este alimento orgânico no futuro. \\
\hline & PCI_2 & Eu pretendo comprar este alimento orgânico. \\
\hline & PCI_3 & Vou fazer um esforço para comprar este alimento orgânico. \\
\hline
\end{tabular}

\section{*Variáveis Excluídas}

Fonte: Resultados da pesquisa. 


\section{Anexo 2}

\section{Dados Socio - Demográficos}

\begin{tabular}{lcc}
\hline Características da amostra & Número & $\%$ \\
\hline Gênero & & \\
Mulher & 479 & $73,58 \%$ \\
Homem & 172 & $26,42 \%$ \\
Idade & 92 & \\
entre 18 e 24 anos & 141 & $21,13 \%$ \\
entre 25 e 34 anos & 153 & $23,56 \%$ \\
entre 35 e 44 anos & 138 & $21,20 \%$ \\
entre 45 e 54 anos & 91 & $13,98 \%$ \\
entre 55 e 64 anos & 36 & $5,53 \%$ \\
Mais de 65 anos & & \\
Nível Educacional & 11 & $1,69 \%$ \\
Ensino fundamental & 55 & $8,45 \%$ \\
Ensino Médio & 317 & $48,69 \%$ \\
Superior & 268 & $41,17 \%$ \\
Pós-graduação (mestrado ou doutorado) & & \\
Ocupação & 111 & $17,05 \%$ \\
Estudante & 60 & $9,22 \%$ \\
Trabalhos domésticos & 59 & $9,06 \%$ \\
Aposentado & 244 & $37,48 \%$ \\
Empregado & 169 & $25,96 \%$ \\
Empresário & 8 & $1,23 \%$ \\
Desempregad0 & 651 & $100 \%$ \\
\hline Total de respondentes & & \\
\hline
\end{tabular}

Fonte: Resultados da Pesquisa. 


\section{Anexo 3}

Validade Discriminante - Critério de Chin (1998) -Matriz de Tabulação das Cargas Fatoriais Cruzadas ( $n=651)$

\begin{tabular}{|c|c|c|c|c|c|c|}
\hline Item & $\begin{array}{l}\text { Importância } \\
\text { da } \\
\text { Informação } \\
\text { do Produto }\end{array}$ & $\begin{array}{c}\text { Critério de } \\
\text { Preço }\end{array}$ & Saúde & Conveniência & Atitude & $\begin{array}{l}\text { Intenção de } \\
\text { Compra }\end{array}$ \\
\hline IPI_1 & 0,781 & 0,257 & 0,509 & 0,179 & 0,303 & 0,378 \\
\hline IPI _2 & $\mathbf{0 , 8 3 7}$ & 0,294 & 0,508 & 0,206 & 0,251 & 0,403 \\
\hline IPI_3 & 0,873 & 0,312 & 0,466 & 0,211 & 0,236 & 0,387 \\
\hline PRC_1 & 0,282 & 0,793 & 0,158 & 0,060 & 0,134 & 0,140 \\
\hline PRC _2 & 0,293 & 0,809 & 0,270 & 0,148 & 0,223 & 0,206 \\
\hline PRC _3 & 0,255 & 0,798 & 0,190 & 0,050 & 0,126 & 0,154 \\
\hline HLT_1 & 0,452 & 0,235 & 0,826 & 0,257 & 0,422 & 0,472 \\
\hline HLT_2 & 0,522 & 0,206 & 0,825 & 0,236 & 0,469 & 0,611 \\
\hline HLT_3 & 0,469 & 0,195 & 0,777 & 0,185 & 0,297 & 0,406 \\
\hline CNV_1 & 0,175 & 0,081 & 0,212 & 0,811 & 0,063 & 0,072 \\
\hline CNV_2 & 0,160 & 0,120 & 0,208 & 0,784 & 0,100 & 0,085 \\
\hline CNV_3 & 0,224 & 0,063 & 0,236 & 0,751 & 0,081 & 0,118 \\
\hline ATT_1 & 0,192 & 0,165 & 0,333 & 0,078 & 0,737 & 0,433 \\
\hline ATT_2 & 0,200 & 0,167 & 0,390 & 0,070 & 0,689 & 0,378 \\
\hline ATT_3 & 0,255 & 0,092 & 0,315 & 0,005 & 0,697 & 0,423 \\
\hline ATT_4 & 0,196 & 0,170 & 0,387 & 0,051 & 0,799 & 0,477 \\
\hline ATT_7 & 0,302 & 0,160 & 0,382 & 0,154 & 0,755 & 0,594 \\
\hline PCI_1 & 0,347 & 0,169 & 0,491 & 0,086 & 0,566 & 0,850 \\
\hline PCI_2 & 0,456 & 0,186 & 0,626 & 0,123 & 0,559 & 0,889 \\
\hline PCI_3 & 0,419 & 0,196 & 0,491 & 0,097 & 0,545 & 0,877 \\
\hline
\end{tabular}

Fonte: Resultados da Pesquisa. 